\title{
Liquidity, Volatility, and Equity Trading Costs Across Countries and Over Time
}

\author{
By: Ian Domowitz, Jack Glen and Ananth Madhavan
}

Working Paper Number 322

March 2000 


\title{
Liquidity, Volatility, and Equity Trading Costs Across Countries and Over Time
}

\author{
Ian Domowitz* \\ Jack Glen $^{\dagger}$ \\ and \\ Ananth Madhavan ${ }^{\ddagger}$
}

Current Version: April 10, 2000

* Mary Jean and Frank P. Smeal Professor of Finance, Smeal College of Business Administration, Pennsylvania State University, University Park, PA 16802, Tel: (814)-863-5620; E-mail: Domowitz@psu.edu

$\dagger \quad$ Portfolio Strategist, International Finance Corporation, 2121 Pennsylvania Avenue N.W., Washington, DC 20433, Tel: (202)-473-8641; E-mail: Jglen@ifc.org

$\ddagger \quad$ Professor of Finance and Business Economics, Marshall School of Business, 701 Exposition Boulevard, University of Southern California, Los Angeles, CA 90089, Tel: (213)740-6519; E-mail: Amadhava@bus.usc.edu

We are very grateful to Elkins/McSherry Inc. for assistance in obtaining the trading data used here and to Vladimir Atanasov for expert research assistance. Financial assistance was provided by the Institute for Quantitative Research in Finance (Domowitz and Madhavan) and we thank them for their support and encouragement. We also thank Frank de Jong, Bruce Lehman, and participants at the Latin American Econometric Society Meetings (Cancun, 1999), Conference on Equity Market Development in Emerging and Transition Economies (Amsterdam, 1999), and Goldman Sachs Asset Management for many useful comments. Any errors are entirely our own.

(C) Ian Domowitz, Jack Glen, and Ananth Madhavan, 2000. 


\title{
Liquidity, Volatility, and Equity Trading Costs Across Countries and Over Time
}

\begin{abstract}
Actual investment performance reflects the underlying strategy of the portfolio manager and the execution costs incurred in realizing those objectives. Execution costs, especially in illiquid markets, can dramatically reduce the notional return to an investment strategy. This paper examines the interactions between cost, liquidity, and volatility, and analyzes their determinants using panel-data for 42 countries from September 1996 to December 1998. We document wide variation in trading costs across countries; emerging markets in particular have significantly higher trading costs even after correcting for factors affecting costs such as market capitalization and volatility. We analyze the inter-relationships between turnover, equity trading costs, and volatility, and investigate the impact of these variables on equity returns. In particular, we show that increased volatility, acting through costs, reduces a portfolio's expected return. However, higher volatility reduces turnover also, mitigating the actual impact of higher costs on returns. Further, turnover is inversely related to trading costs, providing a possible explanation for the increase in turnover in recent years. The results demonstrate that the composition of global efficient portfolios can change dramatically when cost and turnover are taken into account.
\end{abstract}




\section{Introduction}

Investment performance reflects two factors: (1) The underlying investment strategy of the portfolio manager, and (2) The execution costs incurred in realizing those objectives. Recent evidence shows that execution costs can be large, often enough to substantially reduce or even eliminate the notional or "paper" return to an investment strategy. This is especially true in an international context, where execution costs are generally greater than in the United States and liquidity is sometimes scarce. Indeed, most portfolio managers regularly monitor their equity transactions costs, and few believe that such costs are not important to their bottom line.

An analysis of the magnitude and determinants of execution costs is valuable for other reasons. Execution costs vary systematically with market liquidity and return volatility, factors that must be considered when assessing the viability of alternative global investment strategies. ${ }^{1}$ Global mean-variance efficient portfolios (and the perceived gain from international diversification) are affected by the inclusion of execution costs into return computations. Differences in trading costs and liquidity across markets are often cited as important factors in the international competition for order flow, and might shed light on the relative merits of different market designs. Cost considerations in emerging markets are especially relevant from a public policy perspective. For example, in emerging markets, large orders often result in substantial price movements raising concerns that foreign capital flows ("hot money") might destabilize domestic markets. ${ }^{2}$ Large costs in emerging markets may also induce corporations to cross-list their stock in more liquid, developed markets, thereby hindering domestic market development. Finally, innovations in technology often are driven by cost considerations.

Yet, except for a handful of studies, there have been no attempts to analyze differences in trading costs and their determinants on a global basis. ${ }^{3}$ This reflects difficulties in obtaining a common metric for trading costs across markets and over time, and matching this metric with

\footnotetext{
${ }^{1}$ Bekaert and Harvey (1995). The joint analysis of volatility, costs and liquidity is also of interest because the risk premium reflects compensation for transactions costs and illiquidity. See Brennan and Subrahmanyam (1996) and Luttmer (1999).

${ }^{2}$ Choe, Kho, and Stulz (1999) provide an analysis of this issue for Korea.

3 The leading exception is Perold and Sirri (1993), using much older and less comprehensive data than now are available. The literature on U.S. markets includes Huang and Stoll (1996), Chan and Lakonishok (1997), and Keim and Madhavan (1997), among others.
} 
relevant auxiliary data. This paper examines magnitude and determinants of execution costs and analyzes the interactions between cost, liquidity, and volatility using panel-data for a broad sample of 42 countries from September 1996 to December 1998.

Our analysis provides several new and interesting results. We document wide variation in one-way equity trading costs across countries. Transactions costs are economically significant when juxtaposed against realized returns. Interestingly, transaction costs in emerging markets are significantly higher than in developed markets, even after correcting for factors affecting costs such as market capitalization and volatility. This is important because it suggests that reducing the cost of capital may be an important motivation for firms in emerging markets to cross-list their shares or issue American Depository Receipts (ADRs) in US markets. Implicit costs, such as market impact, represent roughly one-third of total cost, indicating the importance of estimating and monitoring these costs.

The panel nature of our data allows us to analyze the determinants of execution costs, and the interaction of costs, liquidity, and return volatility, both across countries and over time. Using a triangular panel-data model we find strong relationships between the variables of interest and shed light on the degree to which liquidity and costs are predictable in practice. Our results suggest that the composition of global efficient portfolios can change dramatically when costs are taken into account. We analyze the inter-relationships between turnover, equity trading costs, and volatility, and investigate the impact of these variables on equity returns. ${ }^{4}$

The paper proceeds as follows. Section 2 provides an overview of the data and our procedures to measure transaction costs; Section 3 summarizes the empirical evidence concerning the magnitude of international equity trading costs; Section 4 turns to an analysis of the determinants of costs; Section 5 provides a discussion of how costs affect the construction of global efficient portfolios; Section 6 examines the inter-relationships between turnover, equity trading costs, and volatility, and investigates their impact on equity returns; and Section 7 concludes.

\footnotetext{
4 Turnover is often used as a proxy for liquidity and we use this variable for this purpose too.
} 


\section{Data Sources and Procedures}

\subsection{Data Sources}

The primary source of data for this study is Elkins/McSherry Co., Inc, a firm that conducts cost studies for institutional traders and serves as a consultant to stock exchanges. Elkins/McSherry receives trade data on all global trades by institutional traders and computes measures of trading costs. In 1998, the institutional traders in the data represented 135 firms, of whom 105 are pension funds, 27 are investment managers, and 4 are brokers. These institutions accounted for 28 billion shares in 632,547 trades, using 700 global managers and 1,000 brokers.

The data we have consist of average trading costs as a percentage of trade value for active managers in a universe of 42 countries. The data are quarterly, from the last quarter of 1995 through the third quarter of 1998. Of particular interest, the cost data are broken down into three components: commissions, fees, and market impact costs. We discuss these components in more detail in the following section. There may be trade-offs between the various cost components (i.e., using full commission brokers to minimize price impact but incurring higher fees as a result). Consequently, it is important to measure total trading costs as is done here.

Stock market data are compiled from a variety of sources. Data on turnover (defined as total trading volume divided by average market capitalization) and market capitalization (in millions of U.S. dollars) for emerging markets are obtained from the International Finance Corporation (IFC) Emerging Market Fact Book 1998. For non-emerging markets, data are gathered from Bloomberg Financial Services. ${ }^{5}$

\subsection{Measurement Issues}

It is common to decompose trading costs into two major components: explicit costs and implicit costs. Explicit costs are the direct costs of trading, such as broker commission costs, taxes, etc. While these costs are relatively small in the U.S. and have been declining, they can be large in other countries. Complicating matters, some countries (e.g., the United Kingdom) levy charges on only one side of the transaction, necessitating a breakdown between buys and sells for some mar-

\footnotetext{
5 Countries are grouped into economic regions defined as follows: (1) North America (Canada and US), (2) West Europe (Austria, Belgium, Denmark, Finland, France, Germany, Ireland, Italy, Luxembourg, Netherlands, Norway, Spain, Sweden Switzerland and UK, (3) Latin America (Argentina, Brazil, Chile, Colombia, Mexico, Peru and Venezuela), (4) Asia (Hong Kong, India, Indonesia, Japan, Korea, Malaysia, Philippines, Singapore Taiwan and
} 
kets. Our data breaks down the one-way transaction costs for buys and sells for two such markets, the U.K. and Japan. While the data distinguish between commission charges and other fees, changes in definitions over the sample period render these distinctions suspect. Accordingly, in our analyses we aggregate commission and fee cost into a single category of explicit costs.

Implicit costs represent indirect trading costs, the major one being the price impact of the trade. Unlike explicit costs where there are typically visible accounting charges, there is no such reporting of implicit costs. As a result, there is considerable disagreement over how best to measure implicit trading costs. Bid-ask spread estimates fail to capture the fact that large trades, that exceed the number of shares the market maker is willing to trade at the quoted bid and ask prices, may move prices in the direction of the trade. The resulting "market" or "price impact" of the transaction is the deviation of the transaction price from the "unperturbed price" that would have prevailed had the trade not occurred. This definition also captures one-half of the bid-ask spread.

The unperturbed price is usually defined as a weighted average of the prices surrounding the trade. An example is the popular volume-weighted average of price (VWAP) on the trade day. The approach used by Elkins/McSherry is closest to this approach. Every day, the company computes a benchmark price for every stock in the 42-country universe by taking the mean of the day's open, close, high and low prices. The price impact for a buy order is measured by the percentage difference between the execution price and this benchmark, and the reverse is true for a sell order. Willoughby (1998) reports that the price impacts computed using the Elkins/McSherry methodology are virtually identical to those computed using the VWAP approach. The great advantage of the Elkins/McSherry data is not in their methodology, but rather that their approach to computing implicit costs is the same for all countries, providing a common standard of measurement.

\section{Magnitude of Equity Trading Costs}

\subsection{Cross-Sectional Variation in Total Costs and Composition of Costs}

We begin by examining the pattern of trading costs across countries averaged over the entire sample period. This cross-sectional perspective is useful in that it dramatically illustrates the wide range in trading costs over countries and regions.

Thailand), (5) East Europe (Czech Republic and Hungary), and (6) Emerging Markets (Latin America, East Europe and Asia (excluding Japan), Greece, Portugal, and South Africa). 
Table 1 reports the mean one-way implicit, explicit, and total equity transaction costs (in basis points, as a percentage of trade value) for the 42 countries in our sample over the sample period from September 1996 to December 1998, broken down by economic region. ${ }^{6}$ Also shown in the table are the mean quarterly returns (in basis points) in the period from 1990 to 1998. Several results are of particular interest.

There is enormous variation in one-way equity trading costs across countries, ranging from a high of 198 basis points in Korea to a low of 30 basis points in France. There is considerable consistency in cost rankings from year to year. As reported by Willoughby (1998), the Paris Bourse is consistently one of the lowest exchanges in cost while South Korea is consistently one of the most expensive markets.

A juxtaposition of costs and returns illustrates the importance of trading costs to portfolio trading. The equally-weighted portfolio of all countries has one-way trading costs of 71.3 basis points. If this portfolio turns over every six months, annual average costs of $2 \times 2 \times 71.3=285$ basis points are incurred. By contrast, the average annual portfolio return (pre-cost) is $4 \times 307$ $=1228$ basis points. Trading costs constitute 23 percent of raw returns in this scenario.

There also is variation in the composition of cost across countries, but both implicit and explicit costs are economically substantial in all cases. Overall, explicit costs are roughly twothirds of total cost. This result is remarkably robust across regions, except for North America. The ratio is 62 percent for Latin America, 69 percent for Western Europe, and 62 percent for emerging markets, on average. There are also some emerging markets (e.g., Brazil) with very low implicit costs. This might reflect the investor base, which consists of large institutional traders who tend to concentrate their holdings in emerging markets in blue chip stocks where implicit costs are low. By contrast, previous studies show that in the U.S. implicit costs are much more significant as a fraction of costs, accounting for over 60 percent of the total. In the U.S., explicit costs are 0.2 percent of value and have been declining. This decline may reflect increased institutional presence in the market, resulting in a more competitive environment for trading services (institutions commonly negotiate lower commission rates), technological innovations in trading such as the increased use of low-cost Electronic Crossing Networks (ECNs) by institutional traders, and soft

\footnotetext{
6 Our data contains information on NYSE and Nasdaq-NMS markets, but for reporting purposes we simply report a country average for the US and other countries with multiple markets.
} 
dollar payments, by which brokers return a portion of the stated commission to institutional investors.

The correlation in explicit and implicit costs reinforces the importance of considering both costs together in investment analysis and trading decisions. The sample correlation between explicit costs and implicit costs is positive, ranging from $0.09-0.31$ by year across the sample period, with no discernible trend. This indicates that the two execution costs are not substitutes for each other. Rather, markets with high market impact costs generally are also expensive in terms of explicit charges such as commissions. There are two notable exceptions, in which the correlations are negative within a region, namely East Asia and North America. In North America, for example, commissions and fees have been steadily declining, while market impact costs over the period remain relatively stable, declining only towards the end of 1998.

Finally, transaction costs in emerging markets are significantly higher than in more developed markets. Total costs are 95 percent larger relative to all other markets in the sample, and over double those observed in the U.S. Much of this difference lies in implicit trading costs, where emerging market costs are over 1.5 times those of more developed markets, but explicit costs also are a factor, being 70 percent higher in the emerging markets. We defer a more detailed discussion of this result until we formally analyze the determinants of trading costs and assess whether factors such as market capitalization and volatility can explain the higher cost figures for emerging markets. However, irrespective of the source of these costs, it is worth noting that the large trading cost differential between developed and emerging markets limits the gains from international diversification in these areas. We return to this issue in Section 5.

Although Table 1 reports only the sample mean for the US, our data allow a computation of execution costs across the two major US markets, the NYSE and Nasdaq. The NYSE operates as a specialist-auction market, where immediacy is provided by public limit orders and an exchangedesignated specialist. Nasdaq is a dealer market, where multiple market makers post quotes prior to trading. The extent to which these differences in market structure affect execution costs is an important question. ${ }^{7}$ There is evidence to suggest that quoted and effective spreads on Nasdaq stocks

\footnotetext{
7 Similarly, there are differences between mean buy and sell costs in some countries (e.g., UK) because of factors such as stamp duties that apply only to, say, sales.
} 
are generally wider than comparable exchange-listed stocks. ${ }^{8}$ Using data for 10 quarters, we find that Nasdaq is consistently more expensive than the NYSE, consistent with earlier studies. Over the entire period, the New York Stock Exchange offered the second lowest among all countries; an average of 31 basis points, below the 45 basis points in Nasdaq-NMS stocks.

\subsection{Time-Series Variation in Costs Across Regions}

Longitudinal data allow us to examine the variation in trading costs over time. We are especially interested in whether there are any discernible trends in the pattern of equity trading costs. The sample period covers several events of economic interest. These include European economic integration, financial crises in Latin America, Asia, and East Europe, and intense competition for order flow among securities markets in developed countries arising from technological and regulatory change. Table 2 provides a time-series of average total (one-way) equity trading costs based on quarterly data for the period September 1996-September 1998. Cost estimates are in basis points, and are shown only for regions.

Transactions costs exhibit sharp declines over the period, with the exception of Eastern Europe, ranging from 10 percent in Latin America to 53 percent in North America. Values for the other regions are close to the average decline of 16 percent averaged over all countries. Falling costs are consistent with figures reported by Willoughby (1998). This may appear surprising given the financial market turmoil, but the decline is not uniform over the period. In particular, the percentage drop in costs calculated from the end of 1997 through the third quarter of 1998 is very close to the figures for the whole period. Most regions experience a small increase in costs in the last three quarters of 1997, with Latin America beginning earlier, in the first quarter. In other words, financial market turmoil is represented by higher trading costs in many regions, but the effect is generally small, about a 3 percent increase in Asia, for example.

The composition of trading costs also changes over the period. Overall, implicit costs fall three times faster than explicit costs. This relative decline in costs is observed for Western Europe, Asia, and emerging markets as a group, with declines in explicit costs from 9 to 10 percent, and a fall in implicit costs of 29 to 33 percent. The change in composition of costs in Latin America is the most pronounced, since explicit costs remained stable, while implicit costs fall by 23 percent.

\footnotetext{
8 See, for example, Lee (1993), Huang and Stoll (1996), Chan and Lakonishok (1997), and Keim and Madhavan (1997).
} 
The results reflect technological developments in these markets, including the introduction of sophisticated trading systems, the retrofitting of exchanges (often to automated execution technology), and advances in information dissemination. The composition of costs in North America is basically unchanged over the period. Implicit costs also fall by 51 percent as trading technology advances, and the decline in explicit costs due to brokerage and exchange competition is only slightly higher, at 54 percent.

Although not shown in Table 2, the NYSE and Nasdaq both exhibit declining trading costs. This decline is especially evident in Nasdaq stocks, possibly as a result of increased concern over bid-ask spreads following allegations of implicit collusion by Nasadaq dealers. ${ }^{9}$ It also coincides with the reduction in the minimum tick size from one eighth $(\$ 0.125)$ to one-sixteenth (\$0.0625) which is thought to have reduced spreads.

\section{Determinants of Trading Costs}

\subsection{Interactions Among Trading Costs and Economic Variables}

The wide range in costs documented above naturally leads us to an investigation of the determinants of execution costs. As a simple way of summarizing the interactions among the key variables of interest, we compute the Pearson correlation coefficients for total (one-way) trading costs, explicit costs, implicit costs, turnover, (log) market capitalization, return volatility, a dummy variable for emerging markets, and a dummy variable for markets using automated limit order book trading systems. We first compute sample means for the variables for 42 countries using quarterly data from September 1996 to December 1998 and then estimate correlations across countries. We perform tests of statistical significance at the 5 percent level under the null hypothesis that the correlation coefficient is equal to zero.

Table 3 contains the estimated correlation matrix. Several results are immediate. As expected, implicit costs are inversely related to market capitalization and positively related to volatility; they are also higher in emerging markets. Explicit costs primarily reflect exogenous regulatory factors and show little correlation with the other economic variables. The exception is the emerging market dummy variable, which is not surprising, given that such costs in emerging

\footnotetext{
${ }^{9}$ See also Christie and Schultz (1994), Christie, Harris, and Schultz (1994), and Barclay, Christie, Harris, Kandel, and Schultz (1999).
} 
markets are almost double those in more developed economies. This might arise because competition among brokers is weak in less developed markets, or because such markets simply face more regulation and are less efficient. Volatility is negatively related to market capitalization and is higher in emerging markets. Turnover is not significantly related to the other variables.

It is natural to use the estimates of trading costs to make inferences about the relative efficiency of alternative trading systems. ${ }^{10}$ The countries represented in our sample offer a considerable range of different systems including pure dealer markets (London, Nasdaq), hybrid specialistauction models (NYSE, Frankfurt, Amsterdam), matching systems (Japan), and automated limit order books (Paris, Toronto), the latter being the most common. ${ }^{11}$ Accordingly, we include a dummy variable for markets with an automated limit order book system. As shown in Table 3, the dummy is significantly positively correlated with our emerging markets dummy and negatively related to market capitalization. The two findings are related. Automated systems are cheaper to build and operate than the dealer and floor based systems prevalent on more established markets, and a large percentage of such systems operating today are in emerging markets as a consequence. The ratio of average market capitalization in developed to emerging markets is over 150 at the end of our sample, which, together with the concentration of automation in the emerging sector, partially accounts for the negative correlation with market capitalization. Automated markets also are prevalent in much of Europe. The same connection with market capitalization applies there as well, with capitalization in North America being roughly 12 times that of Western Europe at the end of the period.

Automated systems, by virtue of reduced operating costs, and the possibility of eliminating the need for dealer or specialist intervention, might reduce trading costs, as suggested by Domowitz and Steil (1999) for the U.S. The correlations with cost here are positive, but not statistically significantly different from zero. Again, this appears to be a phenomenon related to the concentration of systems in emerging markets, which exhibit higher costs on average. Examination of the cost rankings in Table 1 reveals that automated systems in more developed venues tend to reduce implicit costs, in particular. Implicit costs for automated markets operating in New Zealand, Austra-

10 See, e.g., Reinganum (1990), Kothare and Laux (1995), Bessembinder and Kaufman (1996), and Huang and Stoll (1996), among others.

11 See Domowitz (1993) for a list of systems and Domowitz and Steil (1999) for an update with respect to conversions of traditional markets to automated systems. 
lia, Spain, Sweden, France, and Italy, for example, are between 5 and 14 basis points, compared with the overall average of 25 basis points and the figure of 30 basis points for the U.S.

\subsection{A Statistical Model of Volatility, Cost, and Turnover}

To better understand the factors affecting trading costs across countries we estimate models of the form

$$
\mathbf{A} y_{i t}=\mathbf{B} x_{i t}+\lambda_{i}+\varepsilon_{i t}
$$

where $y_{i t}=\left(\tau_{i t}, c_{i t}, \sigma_{i t}\right)^{\prime}$. Here, $c_{i t}$ is total costs for each country $i$ at time $t, \tau_{i t}$ is turnover, and $\sigma_{i t}$ is volatility, measured as the absolute value of demeaned stock market index returns. The vector $\boldsymbol{x}_{i t}$ consists of $K$ pre-determined variables, described below. The vector error term, $\eta_{i t}=\lambda_{i}+\varepsilon_{i t}$, is assumed to consist of a random country-specific component, as well as an idiosyncratic term that varies both cross-sectionally and over time. A and $\mathbf{B}$ are $3 \times 3$ and $3 \times K$ coefficient matrices, respectively.

We impose the following restrictions on the A matrix,

$$
\mathbf{A}=\left[\begin{array}{ccc}
1 & -\alpha_{12} & -\alpha_{13} \\
0 & 1 & -\alpha_{21} \\
0 & 0 & 1
\end{array}\right]
$$

The recursive structure implicit in this formulation is economically logical. Volatility is an exogenous driver, a function of market, regional, and country-specific factors. In turn, volatility affects execution costs. Turnover is related to the cost of trading, and may be affected by volatility as well. While economic theory suggests higher costs will reduce turnover, the effect of volatility is ambiguous. Higher volatility may induce more trading because it is associated with a greater dispersion in beliefs. Alternatively, risk averse traders may reduce their trading in volatile markets.

The resulting triangular system is a natural approach to jointly estimating the interactions among the variables of interest while fully utilizing the panel nature of the data, and is consistent with the correlation analysis of the last section. It serves to identify the system, both for the purpose of estimation and for the computation of turnover response functions to follow, in the absence of a large number of exogenous observables available to us. 
We did, however, statistically check for possible effects of turnover on cost and volatility, as well as for the potential of a direct impact of cost on volatility. We find no such significant relationships in the data set. For example, although a case might be made that lower trading costs induce market efficiency, reducing volatility, the evidence does not support such a hypothesis. We also cannot support the proposition that high turnover, representing the possibility of excess trading activity, destabilizes markets, as judged by the effect of turnover on volatility. ${ }^{12} \mathrm{Fi}^{-}$ nally, although trading costs might be considered lower for more active stocks, given evidence from U.S. cross-sectional analysis, such an effect is not independent of market capitalization. As will be seen below, market capitalization has an important impact on costs, and the preliminary analysis shows no additional statistical explanatory power for turnover with respect to cost as a dependent variable.

The cost measures used are total one-way trading costs. Given the trade-offs between implicit and explicit costs, and the changing composition of costs over time, we focus on total costs in our reporting. ${ }^{13}$ Log transformations of all dependent variables are used. The explanatory variables are log market capitalization, and dummy variables for emerging markets and regions including North America, Asia, Latin America, and West Europe. Consistent with previous research from the U.S., we conjecture that trading costs are lower in more developed markets, and are lower in more liquid markets. The emerging markets variable captures residual costs idiosyncratic to the stage of market development. ${ }^{14}$

The financial crises of 1997-1998 primarily affected emerging markets, and for this reason we want to allow for different coefficient estimates for countries that are especially sensitive to foreign capital flows. To accomplish this in a parsimonious manner, we allow the coefficient $\alpha_{\mathrm{ij}}$ to vary for emerging and developed capital markets. Specifically, we posit a relation of the form

$$
\alpha_{i, j}=a_{i, j}^{D}+a_{i, j}^{E} D^{E M G}
$$

\footnotetext{
12 See also Coppejans and Domowitz (2000) for further discussion and references with respect to this point.

13 Estimated models for implicit costs look very much like those for total costs, while explicit cost regressions add nothing beyond the summary statistics already presented, largely picking up regional effects.

14 The analysis of the previous section suggests the use of a latent variable for automated markets. Given the concentration of such markets in emerging economies and in particular regions, the addition of such a variable results in
} 
where $D^{\mathrm{EMG}}$ is a dummy variable taking the value 1 if the country is an emerging market. Similarly, we allow the coefficient on market capitalization to vary with respect to economic development in all regressions.

\subsection{Cross-Sectional Influences on Trading Costs}

Exogenous factors such as the financial crises and the concomitant time series variation in the data may obscure some fundamental influences on cost across countries. We therefore begin by examining a series of cross-sectional regressions. The triangular system is estimated for the second quarter of 1996, 1997, and 1998. Results for the cost equation are reported in Table 4. There are relatively few observations, resulting in larger standard errors, but the equations' adjusted $\mathrm{R}^{2}$ ranges from 0.55 to 0.63 , indicating a good overall fit to the data. ${ }^{15}$ Several results stand out.

Cost increases with volatility in all cross-sections, although this effect generally is muted for emerging markets. Higher costs are associated with emerging trading venues, consistent with the evidence in Table 3. The impact is particularly large in 1998, reflecting the decline in costs in North America and Europe relative to emerging markets, documented in Table 2 and further illustrated by the negative regional effects in the 1998 cross-section. Higher market capitalization appears to reduces costs in emerging markets to a larger extent than in more developed trading areas, but relative to higher average costs. Regional variation plays a secondary role to the emerging market dummy, suggesting that market development rather than geography is the primary factor affecting cost.

\subsection{Results from the Panel Data Model}

The panel data model is estimated by generalized least squares for unbalanced panel data with individual effects (Searle (1971)). Coefficients and standard errors for the complete triangular system are reported in Table 5.16 The effects captured by the turnover model, in particular, are substantive and statistically significantly different from zero, unlike the qualitatively similar

severe multicollinearity, and is omitted. Latent variables indexing regional variation are important to the portfolio analysis to follow in section 5 .

15 Even those studies using the most detailed data on trading currently available still do poorly in terms of predicting costs. For example, Keim and Madhavan (1997) regress estimated costs on proxies for trade difficulty, market-specific factors, and dummy variables for trader identity and style, and report that the regression $R^{2}$ ranges from 0.10 to 0.15 . In other words, more than 85 percent of the variation in U.S. trading costs is idiosyncratic. 
correlations presented previously. Additional structure from the model and estimation procedure, and the ability to parse out country and development effects, combine to produce sharper estimates of the correlations of interest.

Results from the turnover model show that lower costs of trading, usually associated with better liquidity, substantially increase activity. Should costs fall in other developed markets to the extent that they decline in North America over the sample period, turnover is predicted to increase by about 33 percent.

Turnover is less sensitive to cost in emerging markets than in more developed economies. The turnover cost elasticity is less than a fifth of that in non-emerging markets. Further, the emerging market dummy sharply reduces predicted turnover at the mean of the data. This is economically intuitive, because volumes in emerging markets might be driven more by politically exogenous factors such as privatizations, and are less sensitive to costs.

For emerging markets, higher capitalization increases turnover. This reflects a slight decline in emerging market turnover starting in the third quarter of 1997 accompanied by a fall in capitalization of roughly 40 percent over the following period. Cross-sectionally, there is simply more activity in larger capitalization issues in emerging markets. Turnover is lower in more highly capitalized developed markets.

Finally, although higher volatility appears to stimulate trading with shorter holding periods, the effect is statistically and economically negligible. The regional dummies also add little beyond the emerging market dummy, suggesting that market development rather than geographic region is the primary factor affecting activity.

We turn now to the total cost regression. The model fits well with an adjusted R-square of 0.59. Use of time variation in the data through the panel estimation sheds some additional light on the determinants of cost, relative to the cross-sectional analysis. The estimation results combined with the sharp decline in market capitalization over the sample period suggest that capitalization has a negligible, albeit statistically significant, effect on trading costs in emerging markets. The emerging market elasticity is only a tenth of that in more developed trading venues, where it continues to have an economically and statistically significant effect.

\footnotetext{
16 Quarterly time dummies are included in the panel data regressions, but the coefficients are not reported separately
} in the table. 
The model continues to predict higher costs for emerging market countries, but the effect is now reflected in the time series variation in market capitalization. The emerging market dummy variable is negative, measured with a large standard error. The interaction with market capitalization is significantly positive, however, indicating that costs are higher in higher capitalization emerging markets such as Malaysia and Korea. The net impact of these two terms is to produce higher costs for emerging market countries. The variation in the data leading to this result reflects the financial crisis which hit the larger emerging markets - those having the greatest reliance on foreign capital - the hardest.

Volatility continues to have a positive, but economically negligible, impact on cost. The effect for emerging markets is slightly negative, but measured with a large standard error. Towards the end of the sample period, volatility increased due to financial crises in East Asia and Latin America. ${ }^{17}$ Volatility rose 131 percent in East Asia, for example, from the second quarter of 1997 to the second quarter of 1998.

Although not reported in the table, coefficients on time effects reflect the average decline in trading costs over the period. Several factors influencing the time series variation in cost are being captured, of which the following are illustrative. Competition between markets for international order flow is increasing (Foerster and Karolyi (1999)), which can reduce domestic market spreads (Domowitz, Glen, and Madhavan (1998)). The widespread adoption of automated limit order book systems is a factor in reducing costs. Domowitz and Steil (1999), for example, document a decrease in explicit costs for listed stocks, and in total costs for OTC shares, of 60 percent and 30 percent, respectively, from trading on automated systems in the U.S. relative to traditional trading systems. ${ }^{18}$ Finally, there is increased competitive pressure from new trading systems and regulatory authorities to reduce costs. ${ }^{19}$

Finally, the volatility regression shows that emerging markets - and Asian markets in particular - experienced higher volatility. Since the financial crisis was concentrated in East Asia and Latin America, this is not surprising. Larger market capitalization in emerging markets

\footnotetext{
17 See Bekaert and Harvey (1997) for an examination of time-variation in volatility in emerging markets.

18 See also Pagano and Röell (1990), Pirrong (1996), and Schack (1999) for evidence on reduction of spreads in automated limit order books, relative to dealer and floor trading venues.

19 Domowitz and Steil (1999) discuss the competitive landscape of exchange services competition. An example of regulatory pressure, and its effects, is given by Barclay, Christie, Harris, Kandel, and Schultz (1999).
} 
tends to damp volatility, as might be expected, but the results for developed and emerging economies alike are statistically and economically negligible.

\section{Global Efficient Portfolios}

\subsection{Costs, Turnover, and the Value of Diversification}

Our analysis suggests that execution costs vary systematically with factors that are relevant for investment strategy. The estimated mean-variance efficient frontier - and hence the perceived gain from international diversification - also will change if execution costs are factored into return computations. This change derives in part from reduced returns, but may also be due to changes in the correlation structure of returns, as costs shift non-uniformly across countries. The effect is compounded because turnover is higher in emerging markets. Consider a portfolio focused on large capitalization issues in developed markets with annual (two-way) turnover represented by purchases and sales of 100 percent, management fee of 0.25 percent, and trading costs of 0.4 percent of value. The total costs are 0.4 percent $\times 100$ percent +0.25 percent $=0.65$ percent of portfolio value. By contrast, consider an emerging market portfolio with annual (twoway) turnover of 160 percent, costs of 1.25 percent of value, and management fee of 1 percent. This portfolio has total costs of 1.25 percent $\times 160$ percent +1 percent $=3$ percent of portfolio value. Thus, ignoring risk, the emerging market portfolio would have to provide additional return of 2.35 percent per year to compensate for additional costs.

We now construct portfolios differentiated by costs and time periods for a set of markets representative of international investors' concerns. The market areas are North America, FranceGermany-U.K., the remainder of Western Europe, Asia, and Latin America. ${ }^{20}$ The holding period is assumed to be four quarters, with 100 percent turnover. We also estimate portfolios based on a two quarter holding period. Returns and standard deviations are reported on a quarterly basis using monthly dollar return data (converted using prevailing exchange rates) in the period from 1990 to 1996, before the start of our sample period.

\footnotetext{
20 North America includes US and Canada, Asia includes Japan, Hong Kong, Indonesia, Korea, Malaysia, Philippines, Singapore, Taiwan and Thailand, FGUK includes France, Germany and UK, West Europe includes Austria, Belgium, Denmark, Finland, Ireland, Italy, Luxembourg, Netherlands, Norway, Portugal, Spain, Sweden and Switzerland, Latin America includes Argentina, Brazil, Chile, Colombia, Mexico, Peru and Venezuela.
} 
The time series of observations is relatively short, and we rely upon cross-sectional variation within regions to help identify the covariance matrix for the mean-variance calculations. ${ }^{21}$ Estimation is based on moment conditions, defined as follows. Let $r_{n t}^{m}$ denote the stock index return for country $n$ in region $m$ at time $t$, while $\bar{r}_{n}^{m}$ is the average return for that country. The conditions defining the variance-covariance structure are given by

$$
E\left[\left(r_{i t}^{s}-\bar{r}_{i}^{s}\right)\left(r_{j t}^{k}-\bar{r}_{j}^{k}\right)\right]=\rho_{s k}
$$

for $s, k=1, \ldots, 6$ regions, and for all countries $i$ in $s$ and $j$ in $k$, where $E$ is the expectations operator. The regional variances are obtained by setting $s=k$. The parameters $\rho_{s k}$ are estimated by method-of-moments based on the longitudinal data within and across regions. The covariance matrix is re-estimated when the returns are adjusted for transactions costs.

Transactions costs have a substantial impact on returns, and a relatively small effect on the variance-covariance matrix of the portfolio. Results by region, and for the minimumvariance portfolio over the full sample are reported in Table 6. For the minimum variance portfolio, transactions costs with annual rebalancing lower returns by 76 basis points, with no reduction in the volatility of the portfolio. Returns net of costs also fall sharply in the tangency portfolio, for which volatility actually increases by 60 basis points once costs due to annual rebalancing are taken into account. Examination of individual regions illustrates the factors contributing to these results. North American returns decline from 9.35 to 8.65 percent, compared to a world without transactions costs, while the standard deviation of returns falls only by 1.6 percent. A very similar impact of transactions costs is observed for other regions. ${ }^{22}$

One way to gauge the impact of transaction costs is to see how the composition of a global efficient portfolio would change as a result of including costs. For simplicity, we focus on the tangency portfolio, adopting the viewpoint of a US investor who views the riskless asset as a US treasury bond. The results, shown in Table 7 for two turnover levels, are dramatic. Indeed, the figures suggest large shifts in the tangency portfolio toward lower cost regions. ${ }^{23}$ The weight

\footnotetext{
21 The results are fundamentally unchanged if Japan is separated from other East Asian countries to form a separate portfolio, but that necessitates computations for Japan based only on a short time series, and is therefore omitted.

22 Given short sale restrictions in many emerging markets, in particular, we impose a short sale constraint in these calculations. This has an effect only with respect to Asia, despite the positive expected return. Given the large trading costs observed in that region, the results are more dramatic if the short sale constraint is removed.

${ }^{23}$ Again, a short sale constraint is imposed, and consequently we omit Asia from the table.
} 
for the low cost European countries increases by 15 percent under semi-annual rebalancing, while that for North America, which includes the relatively high cost Nasdaq market, declines by 36 percent. The implication is that considerable care is needed in constructing global efficient frontiers, both respect to costs and turnover.

\subsection{Impact of Financial Crises}

The full sample results cover two very different time periods, before and after the financial crises of 1997. The poor performance of Asian and Latin American countries means that these areas receive little or no weight in the full sample portfolios, especially once transactions costs are introduced. Also, while returns covariance matrices are not substantially changed once transactions costs are introduced, they are very different over the two periods. Accordingly, we split the sample into the period through the second quarter of 1997 and the period from the third quarter of 1997 to the last quarter of 1998. Returns and covariances are re-estimated, with and without costs, using actual return data in the period and the minimum variance portfolios are recomputed.

Transactions costs generate a 23 percent fall in returns for the minimum variance portfolio in the earlier period. The decline is over 85 percent greater than that observed for the full sample, reflecting in part the larger role played by the Latin American and Asian markets, and their higher transactions costs, in the optimal portfolio construction. The standard deviation of the portfolio falls only by about 5 percent compared to the computations without costs. The decline is only slightly larger than that observed in the full sample.

Costs increase slightly in most regions during the latter part of 1997, but decline in 1998 relative to the period prior to the second quarter of 1997. Returns including trading costs are nevertheless negative over this period outside of Europe. Transactions costs now result in a decline of 0.72 percentage points in returns for the minimum variance portfolio, a 6 percent fall in performance relative to the no cost case. Unlike the first period, however, the standard deviation of the portfolio increases slightly. Thus, costs generate a degradation of returns with a small increase in risk over a period of relative financial turmoil. 


\section{Interactions Between Volatility, Liquidity and Expected Returns}

\subsection{Construction of Response Functions}

We turn now to an investigation of how changes in volatility, market development and costs affect liquidity and expected returns. The triangular panel-data model of Section 4 suggests that these relations can be complex. For example, an exogenous increase in volatility affects liquidity through its direct effect on turnover but also indirectly through its impact on transactions costs. Higher volatility increases costs, which reduces turnover, but also leads to more trading, so that the overall impact on liquidity of a shift on volatility is unclear. We use the panel-data estimates for the period 1996-1998 to construct response functions for the variables of interest. With these response functions in hand we can then investigate the effects of exogenous shifts in the variables of interest on expected returns. We focus here on the expected returns net of costs of a value-weighted global portfolio. ${ }^{24}$

The response functions first translate hypothetical changes in market capitalization, volatility, and market development into changes in transactions costs and turnover. Using the notation of section 4.2, the baseline (no change) case for the first step is defined by

$$
y_{i}^{*}=\mathbf{A}^{-1} \mathbf{B} \bar{x}_{i}
$$

where the bar denotes the time series average of the exogenous variables for each country $i$.

The results of changes to exogenous and endogenous variables in the first step are represented generally by

$$
\hat{y}_{i}=\mathbf{A}^{-1} \mathbf{B} \tilde{x}_{i}+\mathbf{A}^{-1} \widetilde{\varepsilon}_{i}
$$

where the tildes denote values of the variables and innovations as dictated by the experiment. For example, if market capitalization, an element of $x$, is hypothesized to increase by 10 percent for all countries, $\tilde{x}_{i}$ contains 110 percent of average market capitalization for all $i$, together with the latent variables indexing status of development and region, including all interaction terms defined by equation (3). In the case of such a shock to an exogenous variable, the innovations are set to their theoretical mean of zero. A shock to volatility, an endogenous variable, is initialized

\footnotetext{
24 The analysis is also replicated for an equally-weighted portfolio of all countries, the tangency portfolio and the global minimum variance portfolio, as discussed below.
} 
by setting $\tilde{x}_{i}=\bar{x}_{i}$ and $\tilde{\varepsilon}_{i}=\left(0,0, \widetilde{\varepsilon}_{3 i}\right)$. The $\hat{y}_{i}$ obtained for each such experiment are used to construct the portfolio returns in the second step. ${ }^{25}$

The $y^{*}$ are used in the second step to produce baseline portfolio returns net of cost as in the preceding section. For each "experiment," defined as a percentage change in, for example, volatility, quarterly returns net of costs then are produced, and used to construct the valueweighted portfolio returns assuming a given turnover. The baseline, therefore, differs slightly from the results reported previously, since forecasts of costs are used to construct the returns, as opposed to using the actual data by region. Different assumptions regarding turnover give rise to different definitions of net expected returns. In the simplest case turnover is a constant, and the impact of costs is simply to subtract a constant amount from expected returns. Another case of interest is where the portfolio's rebalancing is related to turnover in the constituent countries, as might be the case with an active global fund. Accordingly, we adopt two definitions of net returns corresponding to constant and variable turnover. Formally, the portfolio's expected returns net costs corresponding to constant and variable turnover are defined, respectively, as

$$
\begin{gathered}
r_{C}^{*}=\sum_{i} \omega_{i}\left(\bar{r}_{i}-c_{i} T_{i}\right) \\
r_{V}^{*}=\sum_{i} \omega_{i}\left(\bar{r}_{i}-c_{i} T_{i}\left(\tilde{x}_{i}\right)\right)
\end{gathered}
$$

where, for country $i, \omega_{\mathrm{i}}$ is the portfolio weight (the ratio of the country's total stock market capitalization to the total market capitalization of all 42 sample countries), $\bar{r}_{i}$ is the expected gross return, $c_{i}$ is the round-trip total transactions cost, $T_{i}$ denotes constant turnover, and $T_{i}\left(\tilde{x}_{i}\right)$ allows turnover to be a function of other variables as given by equation (1).

\subsection{Estimates}

Computations are based on the coefficient estimates for the full panel. Perturbations to market capitalization and volatility are calculated from -50 percent to +50 percent, reflecting variation over the sample period, in increments of 0.10 . Since much of the substantive variation in turnover appears to be idiosyncratic, based on the $\mathrm{R}^{2}$ of turnover regressions, responses are

\footnotetext{
25 The covariance matrix is held constant across experiments, corresponding to the baseline case. The changes across experiments in the covariance structure are negligible.
} 
computed with and without the contribution of volatility and capitalization to changes in turnover from a base of 100 percent per quarter.

Figures 1-3 show the effect of exogenous shifts in market capitalization (a proxy for development), volatility, and costs on our liquidity measure, i.e., turnover. Figure 1 graphs annual turnover as a function of market capitalization. It is evident that turnover declines as market capitalization grows, relative to the base case, reflecting the higher turnover in emerging markets. Figure 2 shows annual turnover as a function of volatility. Higher volatility increases turnover, consistent with models where heterogeneity in investors' beliefs is the source of trading volume. Turnover is decreasing in cost, as shown in Figure 3, consistent with the idea that investors' desires to trade are price sensitive.

We turn now to a discussion of how changes in these variables affect expected returns. The direct effect of an increase in capitalization from the baseline to 150 percent of the data average is to increase net returns by about 6.5 percent, a figure that increases slightly once shifts in turnover are taken into account. In the cross-sectional triangular system, an increase in capitalization first drives volatility down. The combination of decreased volatility and higher capitalization unambiguously lowers cost, increasing net returns. Although cost decreases, the other changes dominate, leading to a decline in turnover, further increasing returns. ${ }^{26}$

The direct effect of an increase in volatility on cost is positive, resulting in a decline in net returns. Specifically, an increase of 50 percent in volatility occasions roughly a 5 percent drop in returns for the value-weighted portfolio. If turnover also changes in the fashion predicted by the model, volatility has no substantive effect on portfolio returns net of trading costs. As cost increases together with volatility, turnover declines, canceling out the cost effect. This is illustrated in Figure 4 for the value-weighted portfolio which plots the net of cost annual return against volatility.

As in the last section, we repeat these exercises for the period prior to the financial crises, using the second quarter 1997 cross-sectional estimates of the triangular system and data averages up through that quarter. The qualitative results for the minimum variance portfolio are the

\footnotetext{
26 In interpreting net expected return, it is important to understand that the return in question is the realized annual return given a fixed pre-cost expected return. Clearly, if changes in costs are predictable, this base return would adjust to keep returns net of costs constant.
} 
same as for the overall sample, but robustness is obviously an issue given the lack of observations. The portfolio returns exhibit far less sensitivity to changes in capitalization and volatility, however, during the earlier period. A 50 percent increase in capitalization, for example, results in only a fractional percentage increase in returns net of costs, compared to the much larger movement reported for the full sample. Thus, sensitivity of net returns to the fundamentals represented by our observable variables appears to have increased in recent history.

\section{Conclusion}

Understanding of the magnitude and determinants of execution costs across countries and over time is vital to many practical and academic questions. A partial list of these topics includes the prediction of trading costs under alternative trading strategies, determining the effect of execution costs on realized (or "live") portfolio performance, understanding the behavior of institutional equity traders, making intermarket cost comparisons, and assessing arguments about the nature and causes of market fragmentation. The increased availability of detailed data on institutional equity trades in recent years has allowed us to greatly expand our knowledge of equity trading costs. This paper examines the magnitude and determinants of equity trading costs across a sample of 42 countries using quarterly data from September 1996 to December 1998.

We document a wide range in trading costs across countries. Emerging markets in particular have significantly higher trading costs of almost 46 basis points even after correcting for factors affecting cost such as market capitalization and volatility. Interestingly, costs have generally declined, except in East Europe, despite the recent financial market turmoil. This is consistent with Stulz (1999) who argues that globalization reduces the cost of equity capital because both the expected return that investors require to invest in equity to compensate them for risk and agency costs fall. We also discuss the implications of equity trading costs for policy makers and investors. In particular, we show that differences in trading costs across nations can significantly reduce the benefits to international diversification, partly explaining the "home bias" of domestic investors. ${ }^{27}$

\footnotetext{
27 An extensive literature on the home bias and capital market segmentation exists. See, e.g., Stulz (1981) and Bekaert (1995). Karolyi (1996), Stulz (1999), and Lins, Strickland, and Zenner (1999) discuss how international cross-listing might overcome domestic market segmentation in emerging markets, reducing execution costs and hence improving share values.
} 
Institutional traders and portfolio managers are especially concerned with being able to predict costs in real time. In this respect, the unpredictability of costs is an important factor. If traders are averse to the high variance in costs, they may alter their trading strategies towards strategies that let them better predict and control costs. Examples include crossing systems (where the crossing price is pre-determined), automated limit order book systems, or guaranteed principal bids, where the trading costs are known prior to trading. The extent to which the unpredictability in execution costs has led to innovations in trading technology is still an open question. For this reason, cost prediction is also important from a public policy viewpoint.

To improve our ability to predict execution costs we need to understand why the previous estimates are so noisy. There are two factors that complicate the task of estimating and predicting trading costs. First, while some elements of trading costs (e.g., commissions and taxes) are highly predictable, others (such as opportunity and timing costs) are highly variable and depend heavily on prevailing market conditions. Opportunity costs are also a function of the trader's investment style. For example, an index trader, whose objective is to mimic a benchmark portfolio with minimum tracking error, may incur very low opportunity costs but high price impact and commission costs. By contrast, a value trader, who seeks to identify stocks whose fundamental value exceeds the current stock price, may face large opportunity costs but small commission and price impact costs. Second, there are many unobservable factors that may explain the large variation in execution costs. A partial list of such variables includes trader reputation, skill, investment objectives, and subtleties of the trading process (e.g., upstairs intermediation) that are not easily measured.

The estimated models show strong relationships between the variables of interest and shed light on the degree to which liquidity and costs are predictable in practice. Our results suggest that the composition of global efficient portfolios can change dramatically when cost and turnover are taken into account. We analyze the inter-relationships between liquidity, equity trading costs, and volatility, and investigate the impact of these variables on equity returns. In particular, we show that increased volatility, acting through costs, reduces a portfolio's return. However, higher volatility reduces turnover also, mitigating the impact of higher costs on returns. 


\section{References}

Barclay, M.J., W.G. Christie, J.H. Harris, E. Kandel, and P.H. Schultz, 1999, "The Effects of Market Reform on the Trading Costs and Depths of Nasdaq Stocks," Journal of Finance, $54,1-34$.

Bekaert, G., 1995, Market Integration and Investment Barriers in Emerging Equity Markets, in World Bank Economic Review, 9, 75-107.

Bekaert, G., and C. R. Harvey, 1995, Time Varying World Market Integration, Journal of Finance, 50, 403-444.

Bekaert, G., and C. R. Harvey, 1997, Emerging Market Equity Volatility, Journal of Financial Economics, 43, 29-78.

Bessembinder, H., and H. Kaufman, 1996, "Quotations and Trading Costs on the Domestic Equity Exchanges," Working paper, Arizona State University.

Brennan, M. J., and A. Subrahmanyam, 1996, "Market Microstructure and Asset Pricing: On the Compensation for Illiquidity in Stock Returns," Journal of Financial Economics 41, 441464.

Chan, L., and J. Lakonishok, 1997, "Institutional Equity Trading Costs: NYSE versus Nasdaq," Journal of Finance 52, 713-735.

Choe, H., B. C. Kho, and R. M. Stulz, 1999, Do Foreign Investors Destabilize Stock Markets? The Korean Experience in 1997, Journal of Financial Economics 54, 227-264.

Christie, W., and P. Schultz, 1994, "Why do NASDAQ Market Makers Avoid Odd-Eighth Quotes?" Journal of Finance, 49, 1813-1840.

Christie, W., J. Harris, and P. Schultz, 1994, "Why did NASDAQ Market Makers Stop Avoiding Odd-Eighth Quotes?” Journal of Finance, 49, 1841-1860.

Coppejans, M. and I. Domowitz, 2000, "The Impact of Foreign Equity Ownership on Emerging Market Share Price Volatility," International Finance, forthcoming.

Domowitz, I., 1993, "A Taxonomy of Automated Trade Execution Systems," Journal of International Money and Finance, 12, 607-631.

Domowitz, I., J. Glen, and A. Madhavan, 1998, "International Cross-listing and Order Flow Migration: Evidence From an Emerging Market,” Journal of Finance, 53, 2001-2027.

Domowitz, I. and B. Steil, 1999, "Automation, Trading Costs, and the Structure of the Securities Trading Industry," Brookings-Wharton Papers on Financial Services, 2, 33-92. 
Foerster, S. R., and G. A. Karolyi, 1999, "The Effects of Market Segmentation and Investor Recognition on Asset Prices: Evidence from Foreign Stocks Listing in the United States," Journal of Finance, 54, 981-1013.

Huang, R. and H. Stoll, 1996, "Dealer versus Auction Markets: A Paired Comparison of Execution Costs on NASDAQ and the NYSE," Journal of Financial Economics, 41, 313-357.

Karolyi, G. Andrew, 1996, What Happens To Stocks That List Shares Abroad? A Survey of The Evidence And Its Managerial Implications, Working paper, University of Western Ontario.

Keim, D.B., and A. Madhavan, 1997, "Transaction Costs and Investment Style: An InterExchange Analysis of Institutional Equity Trades," Journal of Financial Economics, 46, 265-292

Kothare, M., and P. Laux, 1995, "Trading Costs and the Trading Systems for Nasdaq Stocks," Financial Analysts Journal, 51, 42-53.

Lins, K., D. Strickland, and M. Zenner, 1999, "Do Non-US Firms Issue Stock on US Markets to Relax Capital Constraints?" Working paper, University of North Carolina.

Luttmer, E., 1999, "What Level of Fixed Costs Can Reconcile Consumption and Stock Returns," Journal of Political Economy 107, 969-997.

Pagano, M., and A. Röell, 1990, Trading Systems in European Stock Exchanges: Current Performance and Policy Options, Economic Policy 10, 65-115.

Perold, A., and E. Sirri, 1993, "The Cost of International Equity Trading," Working paper, Harvard University.

Pirrong, S. C., 1996, Market Liquidity and Depth on Computerized and Open Outcry Trading Systems: A Comparison of DTB and LIFFE Bund Contracts, Journal of Futures Markets $16,519-543$.

Reinganum, M. R., 1990, "Market Microstructure and Asset Pricing: An Empirical Investigation of NYSE and NASDAQ Securities,” Journal of Financial Economics, 28, 127-147.

Schack, J., 1999, Cost Containment, Institutional Investor, (November) 43-49.

Searle, S.R., 1971, Linear Models, John Wiley \& Sons, New York.

Stulz, R. M., 1981, On The Effects of Barriers to International Asset Pricing, Journal of Finance 25, 307-319.

Stulz, R. M., 1999, Globalization of Equity Markets and the Cost of Capital, Working paper, Ohio State University.

Willoughby, J., 1998, “Executions Song,” Institutional Investor, 32(11), 51-56. 


\section{Table 1}

\section{One-Way Equity Trading Costs and Components Across Sample Countries}

This table presents estimates of average one-way equity trading costs in basis points for active managers in 42 countries in the period September 1996-December 1998 based on quarterly data provided by Elkins/McSherry Co., Inc. Explicit costs include both commissions and fees; market impact costs are computed by comparing the trade price to a benchmark price on the day of the trade. Data for the US represents average costs across AMEX, Nasdaq, and NYSE markets. Also shown in the table is the quarterly return in basis points for the country (ignoring transactions costs) in the period 1990-1998.

\begin{tabular}{lcccc}
\hline & Total Costs & $\begin{array}{c}\text { Explicit } \\
\text { Costs }\end{array}$ & $\begin{array}{c}\text { Implicit } \\
\text { Costs }\end{array}$ & $\begin{array}{c}\text { Mean } \\
\text { Return }\end{array}$ \\
\hline Argentina & 76.9 & 47.3 & 29.6 & 725 \\
Australia & 54.7 & 49.5 & 5.2 & 245 \\
Austria & 43.8 & 30.8 & 13.0 & 28 \\
Belgium & 35.0 & 25.4 & 9.6 & 424 \\
Brazil & 58.0 & 36.7 & 21.4 & 551 \\
Canada & 52.4 & 25.3 & 27.1 & 94 \\
Chile & 84.3 & 45.7 & 38.6 & 423 \\
Colombia & 97.5 & 55.3 & 42.2 & 693 \\
Czech Republic & 143.7 & 78.7 & 64.9 & -242 \\
Denmark & 40.7 & 28.1 & 12.6 & 189 \\
Finland & 43.4 & 27.9 & 15.5 & 552 \\
France & 29.5 & 22.8 & 6.7 & 294 \\
Germany & 37.7 & 24.3 & 13.4 & 333 \\
Greece & 65.5 & 58.2 & 7.3 & 559 \\
Hong Kong & 59.8 & 50.6 & 9.1 & 479 \\
Hungary & 143.4 & 74.8 & 68.7 & 473 \\
India & 71.6 & 14.0 & 57.7 & 267 \\
Indonesia & 100.9 & 85.2 & 15.7 & 6 \\
Ireland & 130.7 & 106.0 & 24.7 & 422 \\
Italy & 34.8 & 26.3 & 8.5 & 576 \\
\hline
\end{tabular}

Table 1 (Continued) 


\begin{tabular}{lcccc}
\hline & Total Costs & $\begin{array}{c}\text { Explicit } \\
\text { Costs }\end{array}$ & Implicit Costs & $\begin{array}{c}\text { Mean } \\
\text { Return }\end{array}$ \\
\hline Japan & 41.3 & 31.7 & 9.5 & -115 \\
Korea & 197.5 & 63.1 & 134.4 & 77 \\
Luxembourg & 63.8 & 20.1 & 43.6 & 341 \\
Malaysia & 88.7 & 73.8 & 14.8 & 94 \\
Mexico & 61.7 & 34.4 & 27.3 & 383 \\
Netherlands & 42.2 & 23.0 & 19.3 & 429 \\
New Zealand & 47.2 & 34.0 & 13.3 & 202 \\
Norway & 44.6 & 30.3 & 14.3 & 61 \\
Peru & 95.8 & 60.6 & 35.2 & 301 \\
Philippines & 112.7 & 103.2 & 9.5 & 250 \\
Portugal & 62.7 & 43.8 & 18.9 & 254 \\
Singapore & 77.5 & 60.8 & 16.7 & 205 \\
South Africa & 81.6 & 37.4 & 44.2 & 195 \\
Spain & 41.9 & 32.5 & 9.5 & 343 \\
Sweden & 35.8 & 26.2 & 9.6 & 378 \\
Switzerland & 38.5 & 29.8 & 8.7 & 563 \\
Taiwan & 74.6 & 56.0 & 18.6 & 120 \\
Thailand & 89.1 & 69.6 & 19.4 & 67 \\
Turkey & 64.6 & 41.0 & 23.6 & 208 \\
UK & 54.5 & 39.3 & 15.2 & 296 \\
US & 38.1 & 8.3 & 29.8 & 374 \\
Venezuela & 134.1 & 99.4 & 34.7 & 757 \\
\hline Mean & 71.3 & 46.0 & 25.3 & 307 \\
Std. Dev. & 36.8 & 24.3 & 23.3 & 220 \\
Maximum & 197.5 & 106.0 & 134.4 & 757 \\
Minimum & 29.5 & 8.3 & 5.2 & -242 \\
\hline & & & & \\
\hline
\end{tabular}


Table 2

\section{One-Way Equity Trading Costs Over Time and by Region}

The table presents mean estimates of total (one-way) equity trading costs based on quarterly data provided by Elkins/McSherry Co., Inc for the period September 1996-December 1998. Total costs consist of commissions and fees and market impact costs. Market impacts are computed by comparing the trade price to a benchmark price on the day of the trade. All cost estimates are in basis points.

\begin{tabular}{lccccccc}
\hline Quarter & $\begin{array}{c}\text { All } \\
\text { Countries }\end{array}$ & $\begin{array}{c}\text { North } \\
\text { America }\end{array}$ & $\begin{array}{c}\text { West } \\
\text { Europe }\end{array}$ & $\begin{array}{c}\text { Emerging } \\
\text { Markets }\end{array}$ & $\begin{array}{c}\text { Asia } \\
\text { Europe }\end{array}$ & $\begin{array}{c}\text { Latin } \\
\text { America }\end{array}$ \\
\hline 96 III & 74.9 & 68.2 & 52.0 & 99.7 & 99.1 & 129.0 & 82.2 \\
96 IV & 77.2 & 54.0 & 52.9 & 104.3 & 99.9 & 148.6 & 83.0 \\
97 I & 75.0 & 63.0 & 50.8 & 98.7 & 97.8 & 176.3 & 92.6 \\
97 II & 70.6 & 49.3 & 46.8 & 94.8 & 91.8 & 139.9 & 95.7 \\
97 III & 71.5 & 43.8 & 47.6 & 97.4 & 93.0 & 123.7 & 94.9 \\
97 IV & 73.1 & 51.1 & 50.3 & 98.1 & 94.5 & 130.2 & 89.4 \\
98 I & 67.8 & 45.9 & 44.3 & 92.1 & 90.2 & 133.2 & 79.8 \\
98 II & 64.5 & 35.0 & 44.4 & 86.1 & 86.1 & 157.1 & 75.0 \\
98 III & 62.6 & 32.3 & 43.2 & 83.0 & 81.6 & 147.6 & 74.6 \\
\hline Mean & 70.8 & 49.2 & 48.0 & 94.9 & 92.7 & 142.8 & 85.2 \\
Std. Dev. & 5.0 & 11.8 & 3.6 & 6.8 & 6.1 & 16.6 & 29.1 \\
Maximum & 77.2 & 68.2 & 52.9 & 104.3 & 99.9 & 176.3 & 95.7 \\
Minimum & 62.6 & 32.3 & 43.2 & 83.0 & 81.6 & 123.7 & 74.6 \\
\hline
\end{tabular}


Table 3

\section{Correlation Matrix}

The table presents Pearson correlation coefficients for total (one-way) trading costs, explicit costs, implicit costs, turnover, (log) market capitalization, return volatility and dummy variables for emerging markets and automated limit order book trading systems for 42 countries. We first compute sample means for the variables using quarterly from September 1996-December 1998 and then estimate correlations across countries. An asterisk (*) indicates significance at the 5 percent level in a two-tailed test under the null hypothesis that the correlation coefficient is equal to zero.

\begin{tabular}{|c|c|c|c|c|c|c|c|c|}
\hline & Total Cost & Implicit Cost & Explicit Cost & Turnover & Mkt. Cap. & Volatility & Emg. Market & Automated \\
\hline Total Cost & 1 & $0.784 *$ & $0.762 *$ & -0.110 & $-0.543 *$ & $0.347^{*}$ & $0.642 *$ & 0.018 \\
\hline Implicit Cost & & 1 & 0.196 & -0.152 & $-0.538^{*}$ & $0.368^{*}$ & $0.520 *$ & 0.232 \\
\hline Explicit Cost & & & 1 & -0.024 & -0.296 & 0.166 & $0.473 *$ & 0.045 \\
\hline Turnover & & & & 1 & -0.054 & 0.026 & -0.123 & -0.044 \\
\hline Mkt. Cap. & & & & & 1 & $-0.342 *$ & $-0.466 *$ & $-0.315^{*}$ \\
\hline Volatility & & & & & & 1 & $0.507 *$ & 0.010 \\
\hline Emg. Market & & & & & & & 1 & $0.642 *$ \\
\hline Automated & & & & & & & & 1 \\
\hline
\end{tabular}


Table 4

Cross-Sectional Cost Regressions From the Triangular System

The table presents estimates of cost equations from a triangular system cross-sectional model for 42 countries, for the second quarter of 1996, 1997, and 1998, using Elkins/McSherry data. The dependent variable is (log) total oneway trading cost. The independent variables are (log) market capitalization (measured in billions of U.S. dollars), dummy variables taking the value 1 for markets in emerging markets, Asia, Latin America, and West Europe. Standard errors are in parentheses. An asterisk (*) indicates significance at the 5 percent level.

\begin{tabular}{|c|c|c|c|}
\hline \multirow[b]{2}{*}{ Independent Variables } & \multicolumn{3}{|c|}{ Year } \\
\hline & 1996 & 1997 & 1998 \\
\hline Volatility & $\begin{array}{r}0.031 \\
(0.106)\end{array}$ & $\begin{array}{r}0.027 \\
(0.096)\end{array}$ & $\begin{array}{r}0.081 \\
(0.072)\end{array}$ \\
\hline Market Capitalization & $\begin{array}{r}-0.113 \\
(0.072)\end{array}$ & $\begin{array}{c}-0.122 * \\
(0.053)\end{array}$ & $\begin{array}{l}-0.073 \\
(0.056)\end{array}$ \\
\hline $\mathrm{D}^{\mathrm{EMG}}$ & $\begin{array}{r}0.670 \\
(1.177)\end{array}$ & $\begin{array}{r}0.517 \\
(0.949)\end{array}$ & $\begin{array}{r}2.532 \\
(1.040)\end{array}$ \\
\hline $\mathrm{D}^{\mathrm{EMG}} \times$ Volatility & $\begin{array}{r}-0.160 \\
(0.131)\end{array}$ & $\begin{array}{r}0.061 \\
(0.115)\end{array}$ & $\begin{array}{r}-0.072 \\
(0.102)\end{array}$ \\
\hline $\mathrm{D}^{\mathrm{EMG}} \times$ Market Capitalization & $\begin{array}{r}0.017 \\
(0.096)\end{array}$ & $\begin{array}{r}-0.023 \\
(0.080)\end{array}$ & $\begin{array}{r}-0.188 * \\
(0.090)\end{array}$ \\
\hline $\mathrm{D}^{\mathrm{ASIA}}$ & $\begin{array}{r}0.289 \\
(0.171)\end{array}$ & $\begin{array}{r}0.271 \\
(0.163)\end{array}$ & $\begin{array}{r}0.165 \\
(0.170)\end{array}$ \\
\hline $\mathrm{D}^{\mathrm{LAT}-\mathrm{AM}}$ & $\begin{array}{r}-0.159 \\
(0.182)\end{array}$ & $\begin{array}{r}0.038 \\
(0.177)\end{array}$ & $\begin{array}{l}-0.191 \\
(0.205)\end{array}$ \\
\hline $\mathrm{D}^{\mathrm{uS}}$ & $\begin{array}{r}0.366 \\
(0.407)\end{array}$ & $\begin{array}{r}0.242 \\
(0.290)\end{array}$ & $\begin{array}{r}-0.024 \\
(0.306)\end{array}$ \\
\hline $\mathrm{D}^{\mathrm{EUR}}$ & $\begin{array}{r}-0.178 \\
(0.174)\end{array}$ & $\begin{array}{r}-0.208 \\
(0.182)\end{array}$ & $\begin{array}{l}-0.093 \\
(0.201)\end{array}$ \\
\hline Constant & $\begin{array}{c}5.383 * \\
(0.938)\end{array}$ & $\begin{array}{c}5.390 * \\
(0.665)\end{array}$ & $\begin{array}{l}4.642 * \\
(0.717)\end{array}$ \\
\hline Number of Observations & 38 & 42 & 42 \\
\hline Adjusted R-squared & 0.545 & 0.617 & 0.626 \\
\hline
\end{tabular}




\section{Table 5}

\section{Triangular System Panel-Data Model}

The table presents estimates of a triangular random-effects GLS panel-data model for 42 countries from September 1996-December 1998 using Elkins/McSherry data. The dependent variables are $(\log )$ turnover, $(\log )$ total one-way trading cost, and $(\log )$ return volatility. The independent variables are $(\log )$ market capitalization (measured in billions of U.S. dollars), dummy variables taking the value 1 for markets in emerging markets, Asia, Latin America, and West Europe using the IFC's definitions. Quarterly time dummies are included in the regressions, but not reported in the table. Standard errors are in parentheses. An asterisk (*) indicates significance at the 5 percent level.

\begin{tabular}{|c|c|c|c|}
\hline \multirow[b]{2}{*}{ Independent Variables } & \multicolumn{3}{|c|}{ Dependent Variable } \\
\hline & Turnover & Cost & Volatility \\
\hline Cost & $\begin{array}{c}-0.647 * \\
(0.065)\end{array}$ & & \\
\hline Volatility & $\begin{array}{r}0.004 \\
(0.023)\end{array}$ & $\begin{array}{r}0.004 \\
(0.010)\end{array}$ & \\
\hline Market Capitalization & $\begin{array}{c}-0.293 * \\
(0.065)\end{array}$ & $\begin{array}{c}-0.083^{*} \\
(0.025)\end{array}$ & $\begin{array}{r}0.062 \\
(0.057)\end{array}$ \\
\hline $\mathrm{D}^{\mathrm{EMG}}$ & $\begin{array}{r}-8.356^{*} \\
(1.402)\end{array}$ & $\begin{array}{r}-0.382 \\
(0.437)\end{array}$ & $\begin{array}{r}1.427 \\
(1.079)\end{array}$ \\
\hline $\mathrm{D}^{\mathrm{EMG}} \times$ Volatility & $\begin{array}{r}0.017 \\
(0.029)\end{array}$ & $\begin{array}{r}-0.019 \\
(0.013)\end{array}$ & \\
\hline $\mathrm{D}^{\mathrm{EMG}} \times$ Cost & $\begin{array}{l}0.530^{*} \\
(0.211)\end{array}$ & & \\
\hline $\mathrm{D}^{\mathrm{EMG}} \times$ Market Capitalization & $\begin{array}{l}0.571 * \\
(0.084)\end{array}$ & $\begin{array}{c}0.075^{*} \\
(0.036)\end{array}$ & $\begin{array}{l}-0.065 \\
(0.099)\end{array}$ \\
\hline $\mathrm{D}^{\mathrm{ASIA}}$ & $\begin{array}{r}0.075 \\
(0.385)\end{array}$ & $\begin{array}{r}0.196 \\
(0.140)\end{array}$ & $\begin{array}{c}0.510 * \\
(0.174)\end{array}$ \\
\hline $\mathrm{D}^{\mathrm{LAT}-\mathrm{AM}}$ & $\begin{array}{r}-0.870 * \\
(0.417)\end{array}$ & $\begin{array}{r}-0.036 \\
(0.151)\end{array}$ & $\begin{array}{l}-0.031 \\
(0.191)\end{array}$ \\
\hline $\mathrm{D}^{\mathrm{us}}$ & $\begin{array}{r}0.877 \\
(0.699)\end{array}$ & $\begin{array}{r}0.079 \\
(0.255)\end{array}$ & $\begin{array}{r}0.014 \\
(0.351)\end{array}$ \\
\hline $\mathrm{D}^{\mathrm{EUR}}$ & $\begin{array}{r}0.528 \\
(0.435)\end{array}$ & $\begin{array}{r}-0.172 \\
(0.155)\end{array}$ & $\begin{array}{r}0.205 \\
(0.186)\end{array}$ \\
\hline Constant & $\begin{array}{l}8.691 * \\
(1.194)\end{array}$ & $\begin{array}{l}4.804^{*} \\
(0.339)\end{array}$ & $\begin{array}{r}0.421 \\
(0.738)\end{array}$ \\
\hline Number of Observations & 372 & 394 & 394 \\
\hline R-squared (Between) & 0.312 & 0.621 & 0.619 \\
\hline R-squared (Overall) & 0.281 & 0.590 & 0.234 \\
\hline
\end{tabular}




\section{Table 6}

\section{Global Efficient Portfolios With and Without Transactions Costs}

This table contains annual returns (in basis points) for North America, France-Germany-UK, Asia, Western Europe, and Latin America, and for the minimum variance and tangency portfolios constructed from those countries and regions. Mean returns for the regions are computed using equity returns to US investors from the period from 1990-1996. The US risk free rate is used in the construction of the tangency portfolio. Transactions costs are computed using Elkins/McSherry data, and the statistics "with transactions costs" are based on (1) annual rebalancing with 100 percent turnover per annum, and (b) semi-annual rebalancing with 100 percent turnover every six months. A short sales constraint is imposed.

\begin{tabular}{lccc}
\hline & $\begin{array}{c}\text { Return Without } \\
\text { Transactions } \\
\text { Costs }\end{array}$ & \multicolumn{2}{c}{$\begin{array}{c}\text { Return With } \\
\text { Transactions } \\
\text { Costs }\end{array}$} \\
\hline & & $\begin{array}{c}\text { Annual } \\
\text { Rebalancing }\end{array}$ & $\begin{array}{c}\text { Semi-annual } \\
\text { Rebalancing }\end{array}$ \\
\cline { 2 - 4 } North America & 935 & 865 & 795 \\
Asia & 525 & 353 & 181 \\
France, Germany, UK & 1233 & 1155 & 1077 \\
West Europe & 1370 & 1276 & 1181 \\
Latin America & 2237 & 2089 & 1942 \\
\hline Minimum Variance Portfolio & 1073 & 997 & 921 \\
Tangency Portfolio & 1300 & 1230 & 1170 \\
\hline
\end{tabular}




\section{Table 7}

\section{Composition of the Global Efficient Tangency Portfolio With and Without Transactions Costs}

This table contains the portfolio weights, in percent, for North America, France-Germany-UK, Western Europe, and Latin America in the global efficient tangency portfolio constructed from those countries and regions. Mean returns for the regions are computed using equity returns to US investors from the period from 1990-1996. The US risk free rate is used in the construction of the tangency portfolio. Transactions costs are computed using Elkins/McSherry data, and the statistics "with transactions costs" are based on (1) annual rebalancing with 100 percent turnover per annum, and (b) semi-annual rebalancing with 100 percent turnover every six months. A short sale constraint is imposed, so that Asia is excluded.

\begin{tabular}{lccc}
\hline & $\begin{array}{c}\text { Portfolio Weight } \\
\text { Without Transac- } \\
\text { tions Costs }\end{array}$ & \multicolumn{2}{c}{$\begin{array}{c}\text { Portfolio Weight With } \\
\text { Transactions } \\
\text { Costs }\end{array}$} \\
\hline & & $\begin{array}{c}\text { Annual } \\
\text { Rebalancing }\end{array}$ & $\begin{array}{c}\text { Semi-annual } \\
\text { Rebalancing }\end{array}$ \\
\cline { 2 - 4 } North America & 26.6 & 22.5 & 16.9 \\
France, Germany, UK & 31.8 & 33.8 & 36.5 \\
West Europe & 31.1 & 32.6 & 34.5 \\
Latin America & 10.5 & 11.1 & 12.1 \\
\hline
\end{tabular}


Figure 1: Annualized Turnover for a Value-Weighted Portfolio of All Countries as a Function of Market Capitalization Based on Triangular Panel-Data Estimates for 1996-1998 function of Market Capitalization

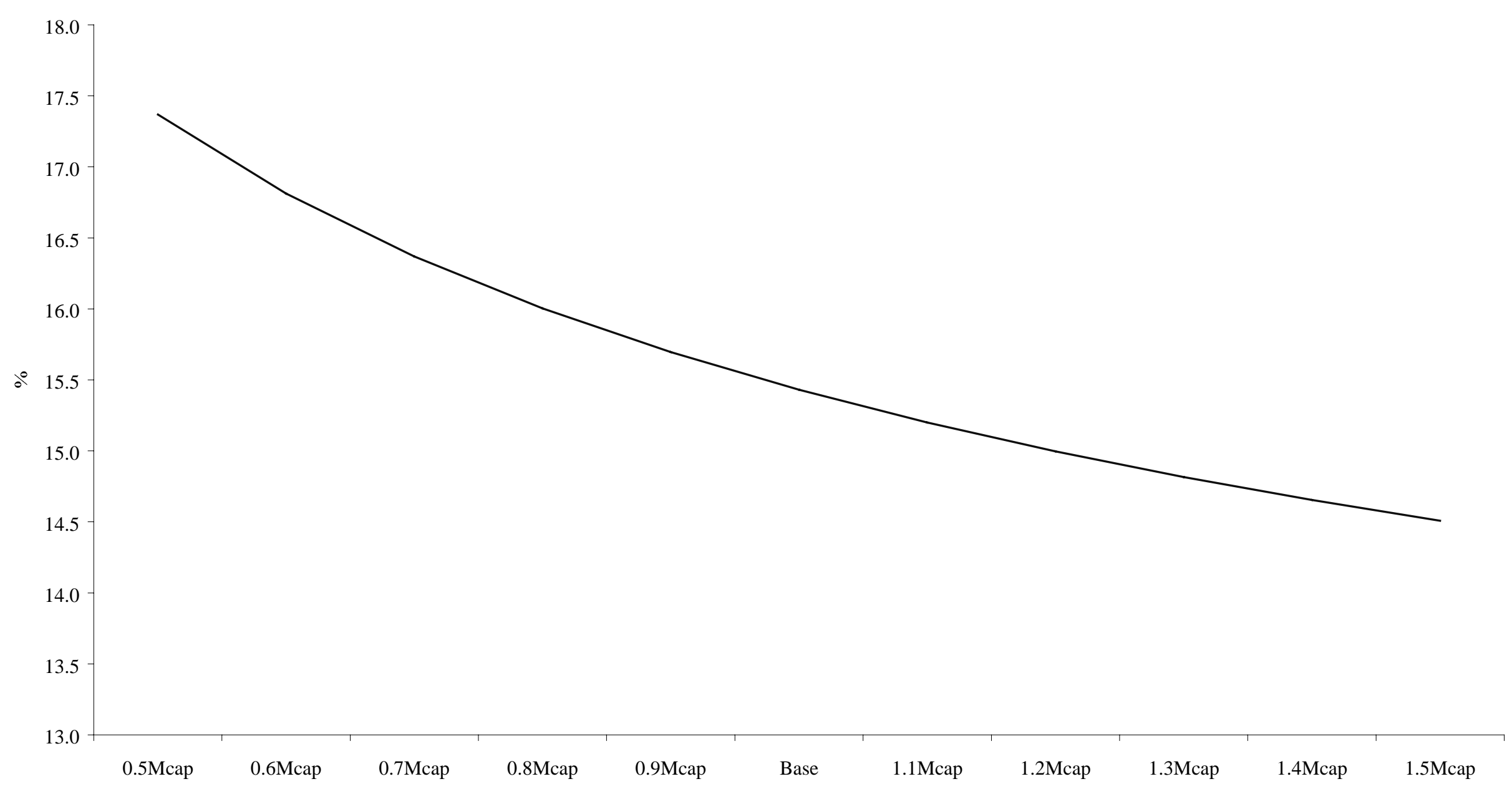


Figure 2: Annualized Turnover for a Value-Weighted Portfolio of All Countries as a

Function of Volatility, Based on Triangular Panel-Data Estimates for 1996-1998

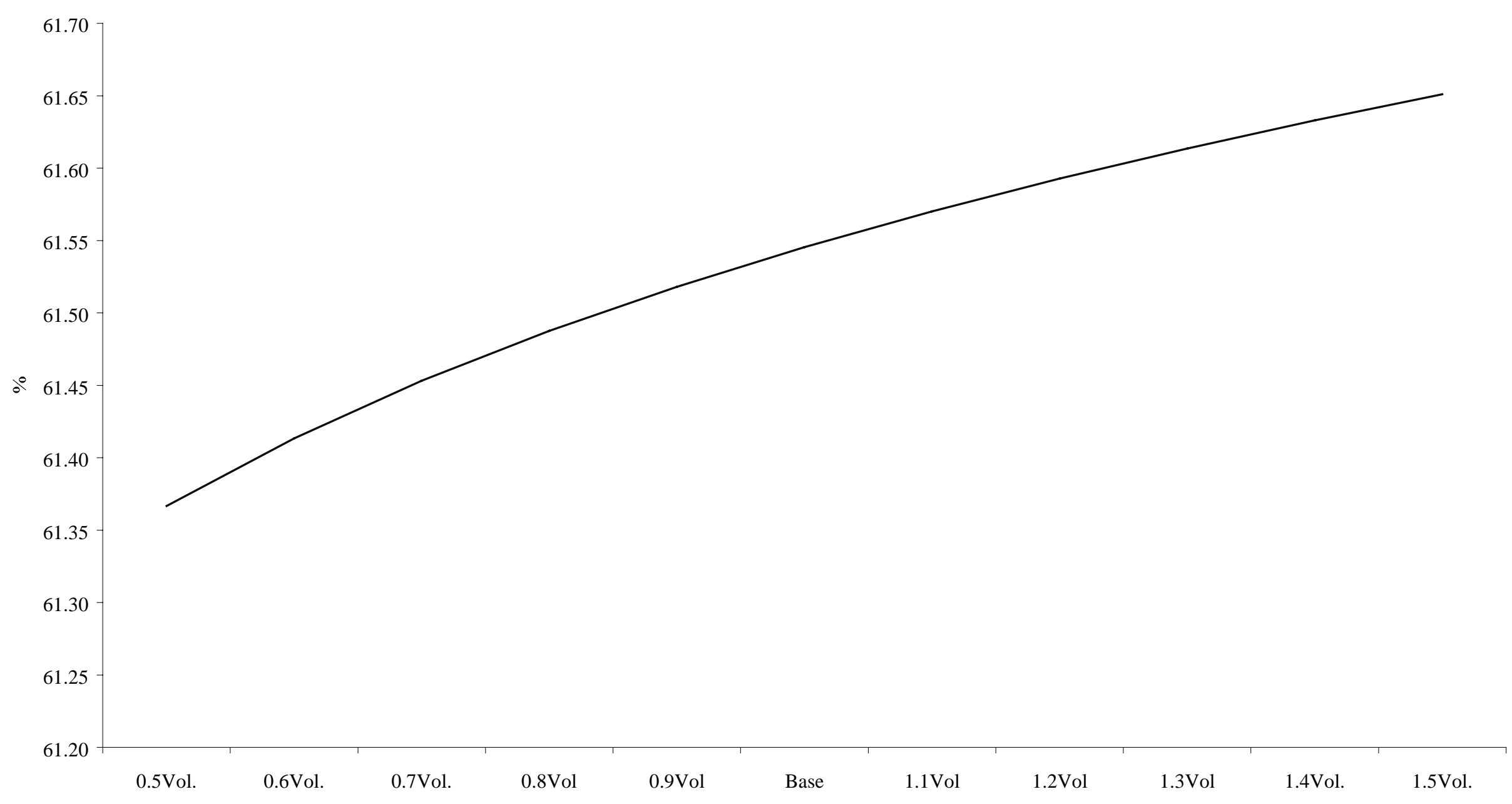


Figure 3: Annualized Turnover for a Value-Weighted Portfolio of All Countries as a

Function of Total Costs Based on Triangular Panel-Data Estimates for 1996-1998

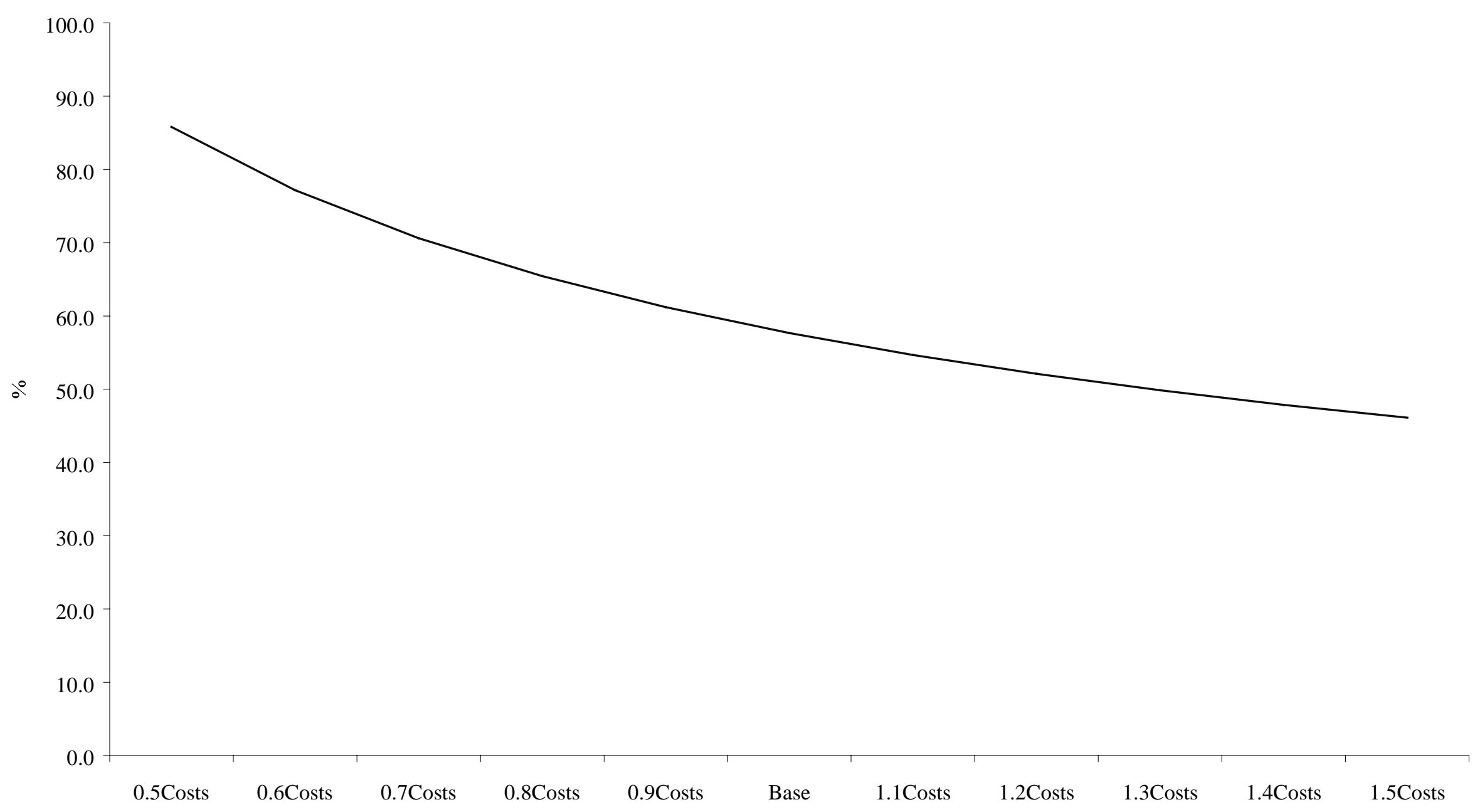


Figure 4: Annualized Net Returns for a Value-Weighted Portfolio of All Countries as a Function of Volatility With and Without a Turnover Equation, Based on Triangular Panel-Data Estimates for 1996-1998

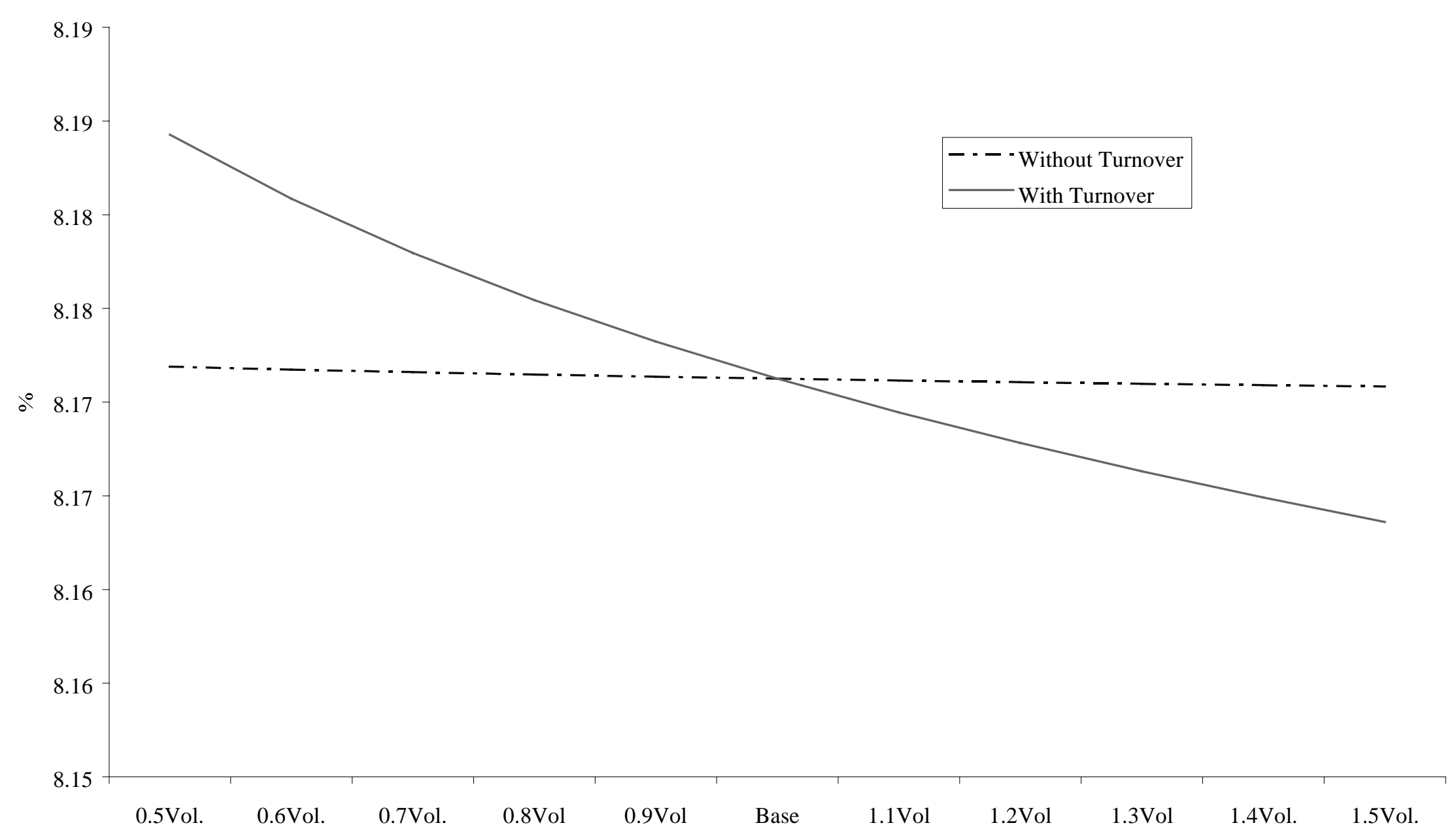




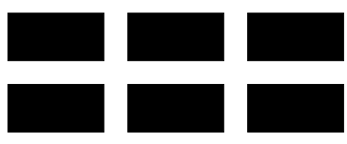

THE WILLIAM DAVIDSON INSTITUTE

AT THE UNIVERSITY OF MICHIGAN BUSINESSSCHOOL

\section{DAVIDSON INSTITUTE WORKING PAPER SERIES}

CURRENT AS OF 4/27/00

\begin{tabular}{|c|c|c|}
\hline Publication & Authors & Date of Paper \\
\hline $\begin{array}{l}\text { No. } 322 \text { Liquidity, Volatility, and Equity } \\
\text { Trading Costs Across Countries and Over } \\
\text { Time }\end{array}$ & $\begin{array}{l}\text { Ian Domowitz, Jack Glen and Ananth } \\
\text { Madhavan }\end{array}$ & March 2000 \\
\hline $\begin{array}{l}\text { No. } 321 \text { Equilibrium Wage Arrears: } \\
\text { Institutional Lock-In of Contractual Failure in } \\
\text { Russia }\end{array}$ & John S. Earle and Klara Z. Sabirianova & June 2000 \\
\hline $\begin{array}{l}\text { No. } 320 \text { Rethinking Marketing Programs for } \\
\text { Emerging Markets }\end{array}$ & Niraj Dawar and Amitava Chattopadhyay & June 2000 \\
\hline $\begin{array}{l}\text { No. } 319 \text { Public Finance and Low Equilibria in } \\
\text { Transition Economies; the Role of Institutions }\end{array}$ & Daniel Daianu and Radu Vranceanu & June 2000 \\
\hline $\begin{array}{l}\text { No. } 318 \text { Some Econometric Evidence on the } \\
\text { Effectiveness of Active Labour Market } \\
\text { Programmes in East Germany }\end{array}$ & Martin Eichler and Michael Lechner & June 2000 \\
\hline $\begin{array}{l}\text { No. } 317 \text { A Model of Russia’s "Virtual } \\
\text { Economy” }\end{array}$ & R.E Ericson and B.W Ickes & May 2000 \\
\hline $\begin{array}{l}\text { No. } 316 \text { Financial Institutions, Financial } \\
\text { Contagion, and Financial Crises }\end{array}$ & Haizhou Huang and Chenggang $X u$ & March 2000 \\
\hline $\begin{array}{l}\text { No. } 315 \text { Privatization versus Regulation in } \\
\text { Developing Economies: The Case of West } \\
\text { African Banks }\end{array}$ & $\begin{array}{l}\text { Jean Paul Azam, Bruno Biais, and } \\
\text { Magueye Dia }\end{array}$ & February 2000 \\
\hline $\begin{array}{l}\text { No. } 314 \text { Is Life More Risky in the Open? } \\
\text { Household Risk-Coping and the Opening of } \\
\text { China's Labor Markets }\end{array}$ & John Giles & April 2000 \\
\hline $\begin{array}{l}\text { No. } 313 \text { Networks, Migration and Investment: } \\
\text { Insiders and Outsiders in Tirupur's } \\
\text { Production Cluster }\end{array}$ & Abhijit Banerjee and Kaivan Munshi & March 2000 \\
\hline $\begin{array}{l}\text { No. } 312 \text { Computational Analysis of the Impact } \\
\text { on India of the Uruguay Round and the } \\
\text { Forthcoming WTO Trade Negotiations }\end{array}$ & $\begin{array}{l}\text { Rajesh Chadha, Drusilla K. Brown, Alan } \\
\text { V. Deardorff and Robert M. Stern }\end{array}$ & March 2000 \\
\hline $\begin{array}{l}\text { No. } 311 \text { Subsidized Jobs for Unemployed } \\
\text { Workers in Slovakia }\end{array}$ & Jan. C. van Ours & May 2000 \\
\hline $\begin{array}{l}\text { No. } 310 \text { Determinants of Managerial Pay in } \\
\text { the Czech Republic }\end{array}$ & $\begin{array}{l}\text { Tor Eriksson, Jaromir Gottvald and Pavel } \\
\text { Mrazek }\end{array}$ & May 2000 \\
\hline $\begin{array}{l}\text { No. } 309 \text { The Great Human Capital } \\
\text { Reallocation: An Empirical Analysis of } \\
\text { Occupational Mobility in Transitional Russia }\end{array}$ & Klara Z. Sabirianova & May 2000 \\
\hline $\begin{array}{l}\text { No. } 308 \text { Economic Development, Legality, and } \\
\text { the Transplant Effect }\end{array}$ & $\begin{array}{l}\text { Daniel Berkowitz, Katharina Pistor, and } \\
\text { Jean-Francois Richard }\end{array}$ & February 2000 \\
\hline $\begin{array}{l}\text { No. } 307 \text { Community Participation, Teacher } \\
\text { Effort, and Educational Outcome: The Case of } \\
\text { El Salvador's EDUCO Program }\end{array}$ & Yasuyuki Sawada & November 1999 \\
\hline $\begin{array}{l}\text { No. } 306 \text { Gender Wage Gap and Segregation in } \\
\text { Late Transition }\end{array}$ & Stepan Jurajda & May 2000 \\
\hline $\begin{array}{l}\text { No. } 305 \text { The Gender Pay Gap in the } \\
\text { Transition from Communism: Some Empirical } \\
\text { Evidence }\end{array}$ & Andrew Newell and Barry Reilly & May 2000 \\
\hline
\end{tabular}

Publications denoted by an asterisk are not available on the Kresge Library webpage (http://www.wdi.bus.umich.edu) 


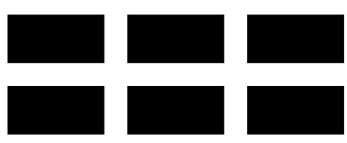

THE WILLIAM DAVIDSON INSTITUTE AT THE UNIVERSITY OF MICHIGAN BUSINESSSCHOOL

\begin{tabular}{|c|c|c|}
\hline $\begin{array}{l}\text { No. } 304 \text { Post-Unification Wage Growth in } \\
\text { East Germany }\end{array}$ & Jennifer Hunt & November 1998 \\
\hline $\begin{array}{l}\text { No. } 303 \text { How Does Privatization Affect } \\
\text { Workers? The Case of the Russian Mass } \\
\text { Privatization Program }\end{array}$ & Elizabeth Brainerd & May 2000 \\
\hline $\begin{array}{l}\text { No. } 302 \text { Liability for Past Environmental } \\
\text { Contamination and Privatization }\end{array}$ & Dietrich Earnhart & March 2000 \\
\hline No. 301 Varieties, Jobs and EU Enlargement & Tito Boeri and Joaquim Oliveira Martins & May 2000 \\
\hline No. 300 Employer Size Effects in Russia & Todd Idson & April 2000 \\
\hline $\begin{array}{l}\text { No. } 299 \text { Information Complements, } \\
\text { Substitutes, and Strategic Product Design }\end{array}$ & $\begin{array}{l}\text { Geoffrey G. Parker and Marshall W. Van } \\
\text { Alstyne }\end{array}$ & March 2000 \\
\hline $\begin{array}{l}\text { No. } 298 \text { Markets, Human Capital, and } \\
\text { Inequality: Evidence from Rural China }\end{array}$ & $\begin{array}{l}\text { Dwayne Benjamin, Loren Brandt, Paul } \\
\text { Glewwe, and Li Guo }\end{array}$ & May 2000 \\
\hline $\begin{array}{l}\text { No. } 297 \text { Corporate Governance in the Asian } \\
\text { Financial Crisis }\end{array}$ & $\begin{array}{l}\text { Simon Johnson, Peter Boone, Alasdair } \\
\text { Breach, and Eric Friedman }\end{array}$ & November 1999 \\
\hline $\begin{array}{l}\text { No. } 296 \text { Competition and Firm Performance: } \\
\text { Lessons from Russia }\end{array}$ & J. David Brown and John S. Earle & March 2000 \\
\hline $\begin{array}{l}\text { No. } 295 \text { Wage Determination in Russia: An } \\
\text { Econometric Investigation }\end{array}$ & Peter J. Luke and Mark E. Schaffer & March 2000 \\
\hline $\begin{array}{l}\text { No. 294: Can Banks Promote Enterprise } \\
\text { Restructuring?: Evidence From a Polish } \\
\text { Bank's Experience }\end{array}$ & John P. Bonin and Bozena Leven & March 2000 \\
\hline $\begin{array}{l}\text { No. 293: Why do Governments Sell Privatised } \\
\text { Companies Abroad? }\end{array}$ & $\begin{array}{l}\text { Bernardo Bortolotti, Marcella Fantini and } \\
\text { Carlo Scarpa }\end{array}$ & March 2000 \\
\hline $\begin{array}{l}\text { No. 292: Going Public in Poland: Case-by- } \\
\text { Case Privatizations, Mass Privatization and } \\
\text { Private Sector Initial Public Offerings }\end{array}$ & Wolfgang Aussenegg & December 1999 \\
\hline $\begin{array}{l}\text { No. 291: Institutional Technology and the } \\
\text { Chains of Trust: Capital Markets and } \\
\text { Privatization in Russia and the Czech } \\
\text { Republic }\end{array}$ & Bruce Kogut and Andrew Spicer & March 1999 \\
\hline $\begin{array}{l}\text { No. 290: Banking Crises and Bank Rescues: } \\
\text { The Effect of Reputation }\end{array}$ & Jenny Corbett and Janet Mitchell & January 2000 \\
\hline $\begin{array}{l}\text { No. 289: Do Active Labor Market Policies } \\
\text { Help Unemployed Workers to Find and Keep } \\
\text { Regular Jobs? }\end{array}$ & Jan C. van Ours & February 2000 \\
\hline $\begin{array}{l}\text { No. 288: Consumption Patterns of the New } \\
\text { Elite in Zimbabwe }\end{array}$ & Russell Belk & February 2000 \\
\hline $\begin{array}{l}\text { No. 287: Barter in Transition Economies: } \\
\text { Competing Explanations Confront Ukranian } \\
\text { Data }\end{array}$ & $\begin{array}{l}\text { Dalia Marin, Daniel Kaufmann and } \\
\text { Bogdan Gorochowskij }\end{array}$ & January 2000 \\
\hline $\begin{array}{l}\text { No. 286: The Quest for Pension Reform: } \\
\text { Poland's Security through Diversity }\end{array}$ & Marek Góra and Michael Rutkowski & January 2000 \\
\hline $\begin{array}{l}\text { No. 285: Disorganization and Financial } \\
\text { Collapse }\end{array}$ & Dalia Marin and Monika Schnitzer & October 1999 \\
\hline $\begin{array}{l}\text { No. 284: Coordinating Changes in M-form } \\
\text { and U-form Organizations }\end{array}$ & $\begin{array}{l}\text { Yingyi Qian, Gérard Roland and } \\
\text { Chenggang } X u\end{array}$ & May 1999 \\
\hline $\begin{array}{l}\text { No. 283: Why Russian Workers Do Not Move: } \\
\text { Attachment of Workers Through In-Kind } \\
\text { Payments }\end{array}$ & Guido Friebel and Sergei Guriev & October 1999 \\
\hline No. 282: Lessons From Fiascos in Russian & Merritt B. Fox and Michael A. Heller & October 1999 \\
\hline
\end{tabular}

Publications denoted by an asterisk are not available on the Kresge Library webpage (http://www.wdi.bus.umich.edu) 


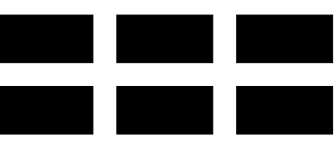

THE WILLIAM DAVIDSON INSTITUTE

AT THE UNIVERSITY OF MICHIGAN BUSINESSSCHOOL

\begin{tabular}{|c|c|c|}
\hline Corporate Governance & & \\
\hline $\begin{array}{l}\text { No. 281: Income Distribution and Price } \\
\text { Controls: Targeting a Social Safety Net } \\
\text { During Economic Transition }\end{array}$ & Michael Alexeev and James Leitzel & March 1999 \\
\hline $\begin{array}{l}\text { No. 280: Starting Positions, Reform Speed, } \\
\text { and Economic Outcomes in Transitioning } \\
\text { Economies }\end{array}$ & William Hallagan and Zhang Jun & January 2000 \\
\hline No. 279: The Value of Prominent Directors & Yoshiro Miwa \& J. Mark Ramseyer & October 1999 \\
\hline No. 278: The System Paradigm & János Kornai & April 1998 \\
\hline $\begin{array}{l}\text { No. 277: The Developmental Consequences of } \\
\text { Foreign Direct Investment in the Transition } \\
\text { from Socialism to Capitalism: The } \\
\text { Performance of Foreign Owned Firms in } \\
\text { Hungary }\end{array}$ & Lawrence Peter King & September 1999 \\
\hline $\begin{array}{l}\text { No. 276: Stability and Disorder: An } \\
\text { Evolutionary Analysis of Russia's Virtual } \\
\text { Economy }\end{array}$ & Clifford Gaddy and Barry W. Ickes & November 1999 \\
\hline $\begin{array}{l}\text { No. 275: Limiting Government Predation } \\
\text { Through Anonymous Banking: A Theory with } \\
\text { Evidence from China. }\end{array}$ & $\begin{array}{l}\text { Chong-En Bai, David D. Li, Yingyi Qian } \\
\text { and Yijiang Wang }\end{array}$ & July 1999 \\
\hline *No. 274: Transition with Labour Supply & Tito Boeri & December 1999 \\
\hline $\begin{array}{l}\text { No. 273: Sectoral Restructuring and Labor } \\
\text { Mobility: A Comparative Look at the Czech } \\
\text { Republic }\end{array}$ & Vit Sorm and Katherine Terrell & November 1999 \\
\hline $\begin{array}{l}\text { *No. 272: Published in: Journal of } \\
\text { Comparative Economics "Returns to Human } \\
\text { Capital Under the Communist Wage Grid and } \\
\text { During the Transition to a Market Economy" } \\
\text { Vol. 27, pp. 33-60 1999. }\end{array}$ & $\begin{array}{l}\text { Daniel Munich, Jan Svejnar and Katherine } \\
\text { Terrell }\end{array}$ & October 1999 \\
\hline $\begin{array}{l}\text { No. 271: Barter in Russia: Liquidity Shortage } \\
\text { Versus Lack of Restructuring }\end{array}$ & Sophie Brana and Mathilde Maurel & June 1999 \\
\hline $\begin{array}{l}\text { No. 270: Tests for Efficient Financial } \\
\text { Intermediation with Application to China }\end{array}$ & Albert Park and Kaja Sehrt & March 1999 \\
\hline $\begin{array}{l}\text { No. 269a: Russian Privatization and } \\
\text { Corporate Governance: What Went Wrong? }\end{array}$ & $\begin{array}{l}\text { Bernard Black, Reinier Kraakman and } \\
\text { Anna Tarassova }\end{array}$ & May 2000 \\
\hline $\begin{array}{l}\text { No. 269: Russian Privatization and Corporate } \\
\text { Governance: What Went Wrong? }\end{array}$ & $\begin{array}{l}\text { Bernard Black, Reinier Kraakman and } \\
\text { Anna Tarassova }\end{array}$ & September 1999 \\
\hline $\begin{array}{l}\text { No. 268: Are Russians Really Ready for } \\
\text { Capitalism? }\end{array}$ & Susan Linz & September 1999 \\
\hline $\begin{array}{l}\text { No. 267: Do Stock Markets Promote } \\
\text { Economic Growth? }\end{array}$ & $\begin{array}{l}\text { Randall K. Filer, Jan Hanousek and Nauro } \\
\text { Campos }\end{array}$ & September 1999 \\
\hline $\begin{array}{l}\text { No. 266: Objectivity, Proximity and } \\
\text { Adaptability in Corporate Governance }\end{array}$ & Arnoud W.A Boot and Jonathan R. Macey & September 1999 \\
\hline $\begin{array}{l}\text { No. 265: When the Future is not What it Used } \\
\text { to Be: Lessons from the Western European } \\
\text { Experience to Forecasting Education and } \\
\text { Training in Transitional Economies }\end{array}$ & $\begin{array}{l}\text { Nauro F. Campos, Gerard Hughes, Stepan } \\
\text { Jurajda, and Daniel Munich }\end{array}$ & September 1999 \\
\hline $\begin{array}{l}\text { No. 264: The Institutional Foundation of } \\
\text { Foreign-Invested Enterprises (FIEs) in China }\end{array}$ & Yasheng Huang & September 1999 \\
\hline No. 263: The Changing Corporate & Erik Berglof and Ernst-Ludwig von & June 1999 \\
\hline
\end{tabular}

Publications denoted by an asterisk are not available on the Kresge Library webpage (http://www.wdi.bus.umich.edu) 


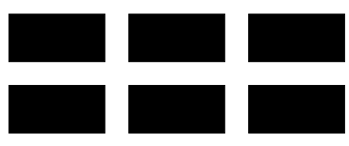

THE WILLIAM DAVIDSON INSTITUTE

AT THE UNIVERSITY OF MICHIGAN BUSINESSSCHOOL

\begin{tabular}{|c|c|c|}
\hline $\begin{array}{l}\text { Governance Paradigm: Implications for } \\
\text { Transition and Developing Countries }\end{array}$ & Thadden & \\
\hline No. 262: Law Enforcement and Transition & Gerard Roland and Thierry Verdier & May 1999 \\
\hline $\begin{array}{l}\text { No. 261: Soft Budget Constraints, Pecuniary } \\
\text { Externality, and the Dual Track System }\end{array}$ & Jiahua Che & June 2000 \\
\hline $\begin{array}{l}\text { No. 260: Missing Market in Labor Quality: } \\
\text { The Role of Quality Markets in Transiton }\end{array}$ & Gary H. Jefferson & July 1999 \\
\hline $\begin{array}{l}\text { No. 259: Do Corporate Global Environmental } \\
\text { Standards in Emerging Markets Create or } \\
\text { Destroy Market Value }\end{array}$ & $\begin{array}{l}\text { Glen Dowell, Stuart Hart and Bernard } \\
\text { Yeung }\end{array}$ & June 1999 \\
\hline $\begin{array}{l}\text { No. 258: Public Training and Outflows from } \\
\text { Unemployment }\end{array}$ & Patrick A. Puhani & June 1999 \\
\hline $\begin{array}{l}\text { No. 257: Ownership Versus Environment: } \\
\text { Why are Public Sector Firms Ineffecient? }\end{array}$ & Ann P. Bartel and Ann E. Harrison & June 1999 \\
\hline $\begin{array}{l}\text { No. 256: Taxation and Evasion in the } \\
\text { Presence of Exortion by Organized Crime }\end{array}$ & $\begin{array}{l}\text { Michael Alexeev, Eckhard Janeba and } \\
\text { Stefan Osborne }\end{array}$ & November 1999 \\
\hline $\begin{array}{l}\text { No. 255: Revisiting Hungary's Bankruptcy } \\
\text { Episode }\end{array}$ & John P. Bonin and Mark E. Schaffer & September 1999 \\
\hline $\begin{array}{l}\text { No. 254: FDI in Emerging Markets: A Home- } \\
\text { Country View }\end{array}$ & Marina v.N Whitman & June 1999 \\
\hline $\begin{array}{l}\text { No. 253: The Asian Financial Crisis: What } \\
\text { Happened, and What is to be Done }\end{array}$ & Jeffrey D. Sachs and Wing Thye Woo & January 1999 \\
\hline $\begin{array}{l}\text { No. 252: Organizational Law as Asset } \\
\text { Partitioning }\end{array}$ & Henry Hansmann and Reinier Kraakman & September 1999 \\
\hline $\begin{array}{l}\text { No. 251: Consumer Behavior Research in } \\
\text { Emerging Consumer Markets: the Case of the } \\
\text { Optimum Stimulation Level in South Africa }\end{array}$ & $\begin{array}{l}\text { Jan-Benedict E. M. Steenkamp and Steven } \\
\text { M. Burgess }\end{array}$ & September 1999 \\
\hline $\begin{array}{l}\text { No. 250: Property Rights Formation and the } \\
\text { Organization of Exchange and Production in } \\
\text { Rural China }\end{array}$ & $\begin{array}{l}\text { Matthew A. Turner, Loren Brandt, and } \\
\text { Scott Rozelle }\end{array}$ & July 1998 \\
\hline $\begin{array}{l}\text { No. 249: Impacts of the Indonesian Economic } \\
\text { Crisis: Price Changes and the Poor }\end{array}$ & $\begin{array}{l}\text { James Levinsohn, Steven Berry, and Jed } \\
\text { Friedman }\end{array}$ & June 1999 \\
\hline $\begin{array}{l}\text { No. 248: Internal Barriers in the Transition of } \\
\text { Enterprises from Central Plan to Market }\end{array}$ & Charalambos Vlachoutsicos & July 1999 \\
\hline $\begin{array}{l}\text { No. 247: Spillovers from Multinationals in } \\
\text { Developing Countries: the Mechanisms at } \\
\text { Work }\end{array}$ & Richard E. Caves & June 1999 \\
\hline $\begin{array}{l}\text { No. 246: Dynamism and Inertia on the } \\
\text { Russian Labour Market: A Model of } \\
\text { Segmentation }\end{array}$ & $\begin{array}{l}\text { Irena Grosfeld, Claudia Senik-Leygonie, } \\
\text { Thierry Verdier, Stanislav Kolenikov and } \\
\text { Elena Paltseva }\end{array}$ & May 1999 \\
\hline $\begin{array}{l}\text { No. 245: Lessons from Bank Privatization in } \\
\text { Central Europe }\end{array}$ & John Bonin and Paul Wachtel & May 1999 \\
\hline $\begin{array}{l}\text { No. 244: Nominal-Real Tradeoffs and the } \\
\text { Effects of Monetary Policy: the Romanian } \\
\text { Experience }\end{array}$ & Christian Popa & December 1998 \\
\hline $\begin{array}{l}\text { No. 243: Privatization, Political Risk and } \\
\text { Stock Market Development in Emerging } \\
\text { Economies }\end{array}$ & Enrico C. Perotti and Pieter van Oijen & March 1999 \\
\hline $\begin{array}{l}\text { No. 242: Investment Financing in Russian } \\
\text { Financial-Industrial Groups }\end{array}$ & Enrico C. Perotti and Stanislav Gelfer & October 1998 \\
\hline No. 241: Can governments maintain hard & Octavian Carare, Constantijn Claessens, & January 1999 \\
\hline
\end{tabular}

Publications denoted by an asterisk are not available on the Kresge Library webpage (http://www.wdi.bus.umich.edu) 


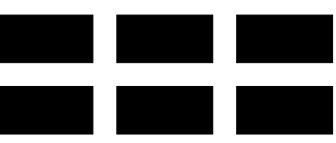

THE WILLIAM DAVIDSON INSTITUTE AT THE UNIVERSITY OF MICHIGAN BUSINESSSCHOOL

\begin{tabular}{|c|c|c|}
\hline $\begin{array}{l}\text { budget constraints? Bank lending and } \\
\text { financial isolation in Romania }\end{array}$ & Enrico C. Perotti & \\
\hline $\begin{array}{l}\text { No. 240: Democratic Institutions and } \\
\text { Economic Reform: the Polish Case }\end{array}$ & $\begin{array}{l}\text { John E. Jackson, Jacek Klich, and } \\
\text { Krystyna Poznanska }\end{array}$ & April 1998 \\
\hline $\begin{array}{l}\text { No. 239: A Longitudinal Study of IJV } \\
\text { Performance in Eastern Europe }\end{array}$ & Keith D. Brouthers and Gary Bamossy & June 1999 \\
\hline $\begin{array}{l}\text { No. 238: Published in: Journal of Business } \\
\text { Venturing, "Firm Creation and Economic } \\
\text { Transitions" Vol. 14, Iss. 5,6 Sep/Nov 1999, } \\
\text { pp. 427-450. }\end{array}$ & $\begin{array}{l}\text { John E. Jackson, Jacek Klich, Krystyna } \\
\text { Poznanska }\end{array}$ & July 1998 \\
\hline $\begin{array}{l}\text { No. 237: Analysis of Entrepreneurial Attitudes } \\
\text { in Poland }\end{array}$ & $\begin{array}{l}\text { John E. Jackson and Aleksander S. } \\
\text { Marcinkowski }\end{array}$ & March 1997 \\
\hline $\begin{array}{l}\text { No. 236: Investment and Finance in De Novo } \\
\text { Private Firms: Empirical Results from the } \\
\text { Czech Republic, Hungary, and Poland }\end{array}$ & $\begin{array}{l}\text { Andrzej Bratkowski, Irena Grosfeld, Jacek } \\
\text { Rostowski }\end{array}$ & April 1999 \\
\hline $\begin{array}{l}\text { No. 235: Does a Soft Macroeconomic } \\
\text { Environment Induce Restructuring on the } \\
\text { Microeconomic Level during the Transition } \\
\text { Period? Evidence from Investment Behavior } \\
\text { of Czech Enterprises }\end{array}$ & Lubomír Lízal & June 1999 \\
\hline $\begin{array}{l}\text { No. 234: Banking Reform in China: Gradually } \\
\text { Strengthening Pillar or Fragile Reed? }\end{array}$ & John Bonin & June 1999 \\
\hline $\begin{array}{l}\text { No. 233: Theories of Soft Budget Constraints } \\
\text { and the Analysis of Banking Crises }\end{array}$ & Janet Mitchell & March 1999 \\
\hline $\begin{array}{l}\text { No. 232: Unemployment Risk, Precautionary } \\
\text { Savings, and Moonlighting in Russia }\end{array}$ & $\begin{array}{l}\text { Alessandra Guariglia and Byung-Yeon } \\
\text { Kim }\end{array}$ & June 1999 \\
\hline $\begin{array}{l}\text { No. 231: Investing in Turbulent Times: The } \\
\text { Investment Behavior of Polish Firms in the } \\
\text { Transition }\end{array}$ & $\begin{array}{l}\text { Josef C. Brada, Arthur E. King, and Chia- } \\
\text { Ying Ma }\end{array}$ & April 1999 \\
\hline $\begin{array}{l}\text { No. 230: The End of Moderate Inflation in } \\
\text { Three Transition Economies? }\end{array}$ & Josef C. Brada and Ali M. Kutan & April 1999 \\
\hline $\begin{array}{l}\text { No. 229: Back to the Future: The Growth } \\
\text { Prospects of Transition Economies } \\
\text { Reconsidered }\end{array}$ & Nauro F. Campos & April 1999 \\
\hline $\begin{array}{l}\text { No. 228: The Enterprise Isolation Program in } \\
\text { Russia }\end{array}$ & Simeon Djankov & April 1999 \\
\hline $\begin{array}{l}\text { No. 227: Published in: Journal of } \\
\text { Comparative Economics, “Ownership } \\
\text { Concentration and Corporate Performance in } \\
\text { the Czech Republic” 27(3), September 1999, } \\
\text { pp. 498-513. }\end{array}$ & Stijn Claessens and Simeon Djankov & April 1999 \\
\hline $\begin{array}{l}\text { No. 226: Unemployment Benefit Entitlement } \\
\text { and Training Effects in Poland during } \\
\text { Transition }\end{array}$ & Patrick A. Puhani & March 1999 \\
\hline $\begin{array}{l}\text { No. 225: Transition at Whirlpool-Tatramat: } \\
\text { Case Studies }\end{array}$ & Hans Brechbuhl and Sonia Ferencikova & March 1999 \\
\hline $\begin{array}{l}\text { No. 224: Measuring Progress in Transition } \\
\text { and Towards EU Accession: A Comparison of } \\
\text { Manufacturing Firms in Poland, Romania, } \\
\text { and Spain }\end{array}$ & $\begin{array}{l}\text { Wendy Carlin, Saul Estrin, and Mark } \\
\text { Schaffer }\end{array}$ & March 1999 \\
\hline $\begin{array}{l}\text { No. 223: Product Market Competition in } \\
\text { Transition Economies: Increasing Varieties }\end{array}$ & Mitsutoshi M. Adachi & March 1999 \\
\hline
\end{tabular}

Publications denoted by an asterisk are not available on the Kresge Library webpage (http://www.wdi.bus.umich.edu) 


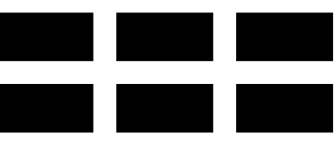

THE WILLIAM DAVIDSON INSTITUTE

AT THE UNIVERSITY OF MICHIGAN BUSINESSSCHOOL

\begin{tabular}{|c|c|c|}
\hline and Consumer Loyalty & & \\
\hline $\begin{array}{l}\text { No. 222: Opaque Markets and Rapid Growth: } \\
\text { the Superiority of Bank-Centered Financial } \\
\text { Systems for Developing Nations }\end{array}$ & Rodney Wallace & July 1999 \\
\hline $\begin{array}{l}\text { No. 221: Technology Spillovers through } \\
\text { Foreign Direct Investment }\end{array}$ & Yuko Kinoshita & January 1999 \\
\hline $\begin{array}{l}\text { No. 220: Managerial, Expertise and Team } \\
\text { Centered Forms of Organizing: A Cross- } \\
\text { Cultural Exploration of Independence in } \\
\text { Engineering Work }\end{array}$ & Leslie Perlow & January 1999 \\
\hline $\begin{array}{l}\text { No. 219: Household Structure and Labor } \\
\text { Demand in Agriculture: Testing for } \\
\text { Separability in Rural China }\end{array}$ & Audra J. Bowlus and Terry Sicular & January 1999 \\
\hline $\begin{array}{l}\text { No. 218: Competing Strategies of FDI and } \\
\text { Technology Transfer to China: American and } \\
\text { Japanese Firms }\end{array}$ & W. Mark Fruin and Penelope Prime & January 1999 \\
\hline $\begin{array}{l}\text { No. } 217 \text { Published in: Journal of } \\
\text { Comparative Economics, "Returns to } \\
\text { Mobility in the Transition to a Market } \\
\text { Economy" Vol. 27, No. 1, March 1999, pp. 4- }\end{array}$ & Tito Boeri and Christopher J. Flinn & January 1999 \\
\hline $\begin{array}{l}\text { No. } 216 \text { Published in: Journal of } \\
\text { Comparative Economics, "Labor Market } \\
\text { Policies and Unemployment in the Czech } \\
\text { Republic." Vol. 27, No. 1, March 1999, pp. } \\
\text { 33-60. }\end{array}$ & Katherine Terrell and Vit Sorm & November 1998 \\
\hline $\begin{array}{l}\text { No. } 215 \text { Published in: Journal of } \\
\text { Comparative Economics, "Active Labor } \\
\text { Market Policies in Poland: Human Capital } \\
\text { Enhancement, Stigmatization or Benefit } \\
\text { Churning?" Vol. 27, No. 1, March 1999, pp. } \\
\text { 61- }\end{array}$ & $\begin{array}{l}\text { Jochen Kluve, Hartmut Lehmann, and } \\
\text { Christoph M. Schmidt }\end{array}$ & December 1998 \\
\hline $\begin{array}{l}\text { No. } 214 \text { Published in: Journal of } \\
\text { Comparative Economics, “Does the Slovenian } \\
\text { Public Work Program Increase Participants' } \\
\text { Chances to Find a Job?” Vol. 27, No.1, } \\
\text { March 1999, pp. 113- }\end{array}$ & Milan Vodopivec & December 1998 \\
\hline $\begin{array}{l}\text { No. } 213 \text { Published in: Journal of } \\
\text { Comparative Economics, "Effects of Active } \\
\text { Labor Market Programs on the Transition } \\
\text { Rate from Unemployment into Regular Jobs in } \\
\text { the Slovak Republic." Vol. 27, No. 1, March } \\
\text { 1999, pp. 90- }\end{array}$ & Martina Lubyova and Jan C. van Ours & December 1998 \\
\hline $\begin{array}{l}\text { No. 212: The Marketing System in Bulgarian } \\
\text { Livestock Production - The Present State and } \\
\text { Evolutionary Processes During the Period of } \\
\text { Economic Transition }\end{array}$ & Yordan Staykov, Team Leader & October 1998 \\
\hline $\begin{array}{l}\text { No. 211: Bankruptcy Experience in Hungary } \\
\text { and the Czech Republic }\end{array}$ & Janet Mitchell & October 1998 \\
\hline $\begin{array}{l}\text { No 210: Values, Optimum Stimulation Levels } \\
\text { and Brand Loyalty: New Scales in New } \\
\text { Populations }\end{array}$ & Steven M. Burgess and Mari Harris & September 1998 \\
\hline No. 209: Inherited Wealth, Corporate Control & Randall K. Morck, David A. Stangeland, & September 1998 \\
\hline
\end{tabular}

Publications denoted by an asterisk are not available on the Kresge Library webpage (http://www.wdi.bus.umich.edu) 


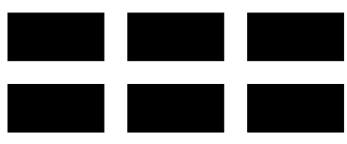

THE WILLIAM DAVIDSON INSTITUTE

AT THE UNIVERSITY OF MICHIGAN BUSINESSSCHOOL

\begin{tabular}{|c|c|c|}
\hline and Economic Growth & and Bernard Yeung & \\
\hline $\begin{array}{l}\text { No. 208: A Cultural Analysis of Homosocial } \\
\text { Reproduction and Contesting Claims to } \\
\text { Competence in Transitional Firms }\end{array}$ & Michael D. Kennedy & July 1998 \\
\hline $\begin{array}{l}\text { No. 207: From Survival to Success: The } \\
\text { Journey of Corporate Transformation at } \\
\text { Haier. Forthcoming in Teaching the } \\
\text { Dinosaurs to Dance: Organizational Change } \\
\text { in Transition Economies ed. Daniel Denison. } \\
\text { No. 206: Why Do People Work If They Are } \\
\text { Not Paid? An Example from Eastern Europe. } \\
\text { Forthcoming in Teaching the Dinosaurs to } \\
\text { Dance: Organizational Change in Transition } \\
\text { Economies ed. Daniel Denison. }\end{array}$ & $\begin{array}{l}\text { Arthur Yeung and Kenneth DeWoskin } \\
\text { Irina L. Zinovieva }\end{array}$ & $\begin{array}{l}\text { July } 1998 \\
\text { May } 1998\end{array}$ \\
\hline $\begin{array}{l}\text { No. 205: Firm Ownership and Work } \\
\text { Motivation in Bulgaria and Hungary: An } \\
\text { Empirical Study of the Transition in the Mid- } \\
\text { 1990s. Forthcoming in Teaching the } \\
\text { Dinosaurs to Dance: Organizational Change } \\
\text { in Transition Economies ed. Daniel Denison. }\end{array}$ & $\begin{array}{l}\text { Robert A. Roe, Irina L. Zinovieva, } \\
\text { Elizabeth Dienes, and Laurens A. ten Horn }\end{array}$ & May 1998 \\
\hline $\begin{array}{l}\text { No. 204: Human Resource Management in the } \\
\text { Restructuring of Chinese Joint Ventures. } \\
\text { Forthcoming in Teaching the Dinosaurs to } \\
\text { Dance: Organizational Change in Transition } \\
\text { Economies ed. Daniel Denison. }\end{array}$ & Nandani Lynton & April 1998 \\
\hline $\begin{array}{l}\text { No. 203: Emergent Compensation Strategies } \\
\text { in Post-Socialist Poland: Understanding the } \\
\text { Cognitive Underpinnings of Management } \\
\text { Practices in a Transition Economy. } \\
\text { Forthcoming in Teaching the Dinosaurs to } \\
\text { Dance: Organizational Change in Transition } \\
\text { Economies ed. Daniel Denison. }\end{array}$ & Marc Weinstein & March 1998 \\
\hline $\begin{array}{l}\text { No. 202: Corporate Transformation and } \\
\text { Organizational Learning: The People's } \\
\text { Republic of China. Forthcoming in Teaching } \\
\text { the Dinosaurs to Dance: Organizational } \\
\text { Change in Transition Economies ed. Daniel } \\
\text { Denison. }\end{array}$ & Meinolf Dierkes and Zhang Xinhua & March 1998 \\
\hline $\begin{array}{l}\text { No. 201: Foreign Direct Investment as a } \\
\text { Factor of Change: The Case of Slovakia. } \\
\text { Forthcoming in Teaching the Dinosaurs to } \\
\text { Dance: Organizational Change in Transition } \\
\text { Economies ed. Daniel Denison. }\end{array}$ & Sonia Ferencikova & February 1998 \\
\hline $\begin{array}{l}\text { No. 200: Radical versus Incremental Change: } \\
\text { The Role of Capabilities, Competition, and } \\
\text { Leaders. Forthcoming in Teaching the } \\
\text { Dinosaurs to Dance: Organizational Change } \\
\text { in Transition Economies ed. Daniel Denison. }\end{array}$ & Karen L. Newman & February 1998 \\
\hline $\begin{array}{l}\text { No. 199: The Emergence of Market Practices } \\
\text { in China's Economic Transition: Price Setting } \\
\text { Practices in Shanghai's Industrial Firms. } \\
\text { Forthcoming in Teaching the Dinosaurs to }\end{array}$ & Douglas Guthrie & February 1998 \\
\hline
\end{tabular}

Publications denoted by an asterisk are not available on the Kresge Library webpage (http://www.wdi.bus.umich.edu) 


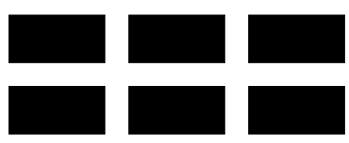

THE WILLIAM DAVIDSON INSTITUTE

AT THE UNIVERSITY OF MICHIGAN BUSINESSSCHOOL

\begin{tabular}{|c|c|c|}
\hline $\begin{array}{l}\text { Dance: Organizational Change in Transition } \\
\text { Economies ed. Daniel Denison. }\end{array}$ & & \\
\hline $\begin{array}{l}\text { No. 198: The Application of Change } \\
\text { Management Methods at Business } \\
\text { Organizations Operating in Hungary: } \\
\text { Challenges in the Business and Cultural } \\
\text { Environment and First Practical Experiences. } \\
\text { Forthcoming in Teaching the Dinosaurs to } \\
\text { Dance: Organizational Change in Transition } \\
\text { Economies ed. Daniel Denison. }\end{array}$ & Dr. János Fehér & January 1998 \\
\hline $\begin{array}{l}\text { No. 197: Organizational Changes in Russian } \\
\text { Industrial Enterprises: Mutation of Decision- } \\
\text { Making Structures and Transformations of } \\
\text { Ownership. Forthcoming in Teaching the } \\
\text { Dinosaurs to Dance: Organizational Change } \\
\text { in Transition Economies ed. Daniel Denison. }\end{array}$ & Igor B. Gurkov & January 1998 \\
\hline $\begin{array}{l}\text { No. 196: Understanding and Managing } \\
\text { Challenges to the Romanian Companies } \\
\text { during Transition. Forthcoming in Teaching } \\
\text { the Dinosaurs to Dance: Organizational } \\
\text { Change in Transition Economies ed. Daniel } \\
\text { Denison. }\end{array}$ & Dan Candea and Rodica M. Candea & January 1998 \\
\hline $\begin{array}{l}\text { No. 195: Insider Lending and Economic } \\
\text { Transition: The Structure, Function, and } \\
\text { Performance Impact of Finance Companies in } \\
\text { Chinese Business Groups. Forthcoming in } \\
\text { Teaching the Dinosaurs to Dance: } \\
\text { Organizational Change in Transition } \\
\text { Economies ed. Daniel Denison. }\end{array}$ & Lisa A. Keister & December 1997 \\
\hline $\begin{array}{l}\text { No. 194: Japanese Investment in Transitional } \\
\text { Economies: Characteristics and Performance. } \\
\text { Forthcoming in Teaching the Dinosaurs to } \\
\text { Dance: Organizational Change in Transition } \\
\text { Economies ed. Daniel Denison. }\end{array}$ & Paul W. Beamish and Andrew Delios & November 1997 \\
\hline $\begin{array}{l}\text { No. 193: Building Successful Companies in } \\
\text { Transition Economies. Forthcoming in } \\
\text { Teaching the Dinosaurs to Dance: } \\
\text { Organizational Change in Transition } \\
\text { Economies ed. Daniel Denison. }\end{array}$ & Dr. Ivan Perlaki & January 1998 \\
\hline $\begin{array}{l}\text { No. 192: Russian Communitariansim: An } \\
\text { Invisible Fist in the Transformation Process of } \\
\text { Russia. Forthcoming in Teaching the } \\
\text { Dinosaurs to Dance: Organizational Change } \\
\text { in Transition Economies ed. Daniel Denison. }\end{array}$ & Charalambos Vlachoutsicos & July 1998 \\
\hline No. 191: Teaching the Dinosaurs to Dance & Michal Cakrt & September 1997 \\
\hline $\begin{array}{l}\text { No. 190: Strategic Restructuring: Making } \\
\text { Capitalism in Post-Communist Eastern } \\
\text { Europe. Forthcoming in Teaching the } \\
\text { Dinosaurs to Dance: Organizational Change } \\
\text { in Transition Economies ed. Daniel Denison. }\end{array}$ & Lawrence P. King & September 1997 \\
\hline $\begin{array}{l}\text { No. 189: Published in: Regional Science and } \\
\text { Urban Economics, "Russia's Internal }\end{array}$ & Daniel Berkowitz and David N. DeJong & July 1998 \\
\hline
\end{tabular}

Publications denoted by an asterisk are not available on the Kresge Library webpage (http://www.wdi.bus.umich.edu) 


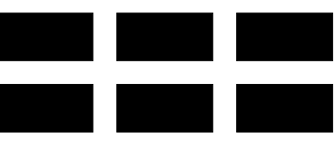

THE WILLIAM DAVIDSON INSTITUTE

AT THE UNIVERSITY OF MICHIGAN BUSINESSSCHOOL

\begin{tabular}{|c|c|c|}
\hline Border”, 29 (5), September 1999. & & \\
\hline $\begin{array}{l}\text { No. 187: Corporate Structure and } \\
\text { Performance in Hungary }\end{array}$ & László Halpern and Gábor Kórsöi & July 1998 \\
\hline $\begin{array}{l}\text { No. 186: Performance of Czech Companies by } \\
\text { Ownership Structure }\end{array}$ & Andrew Weiss and Georgiy Nikitin & June 1998 \\
\hline $\begin{array}{l}\text { No. 185: Firm Performance in Bulgaria and } \\
\text { Estonia: The effects of competitive pressure, } \\
\text { financial pressure and disorganisation }\end{array}$ & Jozef Konings & July 1998 \\
\hline $\begin{array}{l}\text { No. 184: Investment and Wages during the } \\
\text { Transition: Evidence from Slovene Firms }\end{array}$ & Janez Prasnikar and Jan Svejnar & July 1998 \\
\hline $\begin{array}{l}\text { No. 183: Investment Portfolio under Soft } \\
\text { Budget: Implications for Growth, Volatility } \\
\text { and Savings }\end{array}$ & Chongen Bai and Yijiang Wang & \\
\hline $\begin{array}{l}\text { No. 181: Delegation and Delay in Bank } \\
\text { Privatization }\end{array}$ & Loránd Ambrus-Lakatos and Ulrich Hege & July 1998 \\
\hline $\begin{array}{l}\text { No. 180: Financing Mechanisms and } R \& D \\
\text { Investment }\end{array}$ & Haizhou Huang and Chenggang Xu & July 1998 \\
\hline $\begin{array}{l}\text { No. 179: Organizational Culture and } \\
\text { Effectiveness: The Case of Foreign Firms in } \\
\text { Russia }\end{array}$ & Carl F. Fey and Daniel R. Denison & January 1999 \\
\hline $\begin{array}{l}\text { No. 178: Output and Unemployment } \\
\text { Dynamics in Transition }\end{array}$ & Vivek H. Dehejia and Douglas W. Dwyer & January 1998 \\
\hline $\begin{array}{l}\text { No. 177: Published in: Economics of } \\
\text { Transition,, “Bureaucracies in the Russian } \\
\text { Voucher Privatization" Vol. } 8, \text { No. 1, 2000, } \\
\text { pp. 37-57. }\end{array}$ & Guido Friebel & June 1998 \\
\hline $\begin{array}{l}\text { No. 176: Chronic Moderate Inflation in } \\
\text { Transition: The Tale of Hungary }\end{array}$ & János Vincze & June 1998 \\
\hline $\begin{array}{l}\text { No. 175: Privatisation and Market Structure } \\
\text { in a Transition Economy }\end{array}$ & John Bennett and James Maw & June 1998 \\
\hline $\begin{array}{l}\text { No. 174: Ownership and Managerial } \\
\text { Competition: Employee, Customer, or Outside } \\
\text { Ownership }\end{array}$ & Patrick Bolton and Chenggang $X u$ & June 1998 \\
\hline $\begin{array}{l}\text { No. 173: Intragovernment Procurement of } \\
\text { Local Public Good: A Theory of } \\
\text { Decentralization in Nondemocratic } \\
\text { Government }\end{array}$ & Chong-en Bai, Yu Pan and Yijiang Wang & June 1998 \\
\hline $\begin{array}{l}\text { No. 172: Political Instability and Growth in } \\
\text { Proprietary Economies }\end{array}$ & Jody Overland and Michael Spagat & August 1998 \\
\hline $\begin{array}{l}\text { No. 171: Published in Post-Communist } \\
\text { Economies, "Framework Issues in the } \\
\text { Privatization Strategies of the Czech Republic, } \\
\text { Hungary, and Poland" Vol. 11, no. 1 March } \\
\text { 1999. }\end{array}$ & Morris Bornstein & June 1998 \\
\hline $\begin{array}{l}\text { No. 170: Published in: European Journal of } \\
\text { Political Economy "Privatization, Ownership } \\
\text { Structure and Transparency: How to Measure } \\
\text { a Real Involvement of the State" 15(4), } \\
\text { November 1999, pp. 605-18. }\end{array}$ & Frantisek Turnovec & May 1998 \\
\hline $\begin{array}{l}\text { No. } 169 \text { Published in: American Economic } \\
\text { Review, "Unemployment and the Social Safety } \\
\text { Net during Transitions to a Market Economy: }\end{array}$ & $\begin{array}{l}\text { John C. Ham, Jan Svejnar, and Katherine } \\
\text { Terrell }\end{array}$ & December 1998 \\
\hline
\end{tabular}

Publications denoted by an asterisk are not available on the Kresge Library webpage (http://www.wdi.bus.umich.edu) 


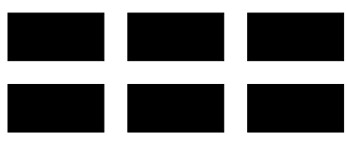

THE WILLIAM DAVIDSON INSTITUTE

AT THE UNIVERSITY OF MICHIGAN BUSINESSSCHOOL

\begin{tabular}{|c|c|c|}
\hline $\begin{array}{l}\text { Evidence from Czech and Slovak Men." Vol. } \\
\text { 88, No. 5, Dec. 1998, pp. 1117-1142. }\end{array}$ & & \\
\hline $\begin{array}{l}\text { No. 167: Voucher Privatization with } \\
\text { Investment Funds: An Institutional Analysis }\end{array}$ & David Ellerman & March 1998 \\
\hline $\begin{array}{l}\text { No. 166: Published in: Marketing Issues in } \\
\text { Transitional Economies, "Value Priorities } \\
\text { and Consumer Behavior in a Transitional } \\
\text { Economy: The Case of South Africa" ed. } \\
\text { Rajeev Batra. }\end{array}$ & $\begin{array}{l}\text { Steven M. Burgess and Jan-Benedict E.M. } \\
\text { Steenkamp }\end{array}$ & August 1998 \\
\hline $\begin{array}{l}\text { No. 164: Finance and Investment in } \\
\text { Transition: Czech Enterprises, 1993-1994 }\end{array}$ & Ronald Anderson and Chantal Kegels & September 1997 \\
\hline $\begin{array}{l}\text { No. 163: European Union Trade and } \\
\text { Investment Flows U-Shaping Industrial } \\
\text { Output in Central and Eastern Europe: } \\
\text { Theory and Evidence }\end{array}$ & Alexander Repkine and Patrick $P$. Walsh & April 1998 \\
\hline $\begin{array}{l}\text { No. 162: Skill Acquisition and Private Firm } \\
\text { Creation in Transition Economies }\end{array}$ & Zuzana Brixiova and Wenli $\mathrm{Li}$ & October 1999 \\
\hline No. 161: Corruption in Transition & Susanto Basu and David D. Li & May 1998 \\
\hline $\begin{array}{l}\text { No. 160a: Tenures that Shook the World: } \\
\text { Worker Turnover in Russia, Poland and } \\
\text { Britain }\end{array}$ & $\begin{array}{l}\text { Hartmut Lehmann and Jonathan } \\
\text { Wadsworth }\end{array}$ & November 1999 \\
\hline $\begin{array}{l}\text { No. 160: Tenures that Shook the World: } \\
\text { Worker Turnover in the Russian Federation } \\
\text { and Poland }\end{array}$ & $\begin{array}{l}\text { Hartmut Lehmann and Jonathan } \\
\text { Wadsworth }\end{array}$ & June 1998 \\
\hline $\begin{array}{l}\text { No. 159: Does Market Structure Matter? New } \\
\text { Evidence from Russia }\end{array}$ & Annette N. Brown and J. David Brown & June 1998 \\
\hline $\begin{array}{l}\text { No. 158: Structural Adjustment and Regional } \\
\text { Long Term Unemployment in Poland }\end{array}$ & Hartmut Lehmann and Patrick P. Walsh & June 1997 \\
\hline $\begin{array}{l}\text { No. 157: Baby Boom or Bust? Changing } \\
\text { Fertility in Post-Communist Czech Republic } \\
\text { and Slovakia }\end{array}$ & Robert S. Chase & April 1998 \\
\hline $\begin{array}{l}\text { No. } 156 \text { Published in: Leadership and } \\
\text { Organization Development Journal, } \\
\text { "Leading Radical Change in Transition } \\
\text { Economies." Vol. 19, No. 6, 1998, pp. 309- } \\
\text { 324. }\end{array}$ & Karen L. Newman & June 1998 \\
\hline $\begin{array}{l}\text { No. } 155 \text { Published in: Oxford Review of } \\
\text { Economic Policy, "From Theory into } \\
\text { Practice? Restructuring and Dynamism in } \\
\text { Transition Economies." Vol. 13, No. } 2 \text {, } \\
\text { Summer 1997, pp. 77-105. } \\
\end{array}$ & Wendy Carlin and Michael Landesmann & June 1997 \\
\hline $\begin{array}{l}\text { No. 154: The Model and the Reality: } \\
\text { Assessment of Vietnamese SOE Reform- } \\
\text { Implementation at the Firm Level }\end{array}$ & $\begin{array}{l}\text { Edmund Malesky, Vu Thanh Hung, Vu Thi } \\
\text { Dieu Anh, and Nancy K. Napier }\end{array}$ & July 1998 \\
\hline $\begin{array}{l}\text { No. } 153 \text { Published in: Journal of } \\
\text { Comparative Economics, "Causes of the Soft } \\
\text { Budget Constraint: Evidence on Three } \\
\text { Explanations." Vol. 26, No. 1, March 1998, } \\
\text { pp. 104-116. }\end{array}$ & David D. Li and Minsong Liang & March 1998 \\
\hline $\begin{array}{l}\text { No. } 152 \text { Published in: Comparative Economic } \\
\text { Studies, "Enterprise Restructuring in Russia's } \\
\text { Transition Economy: Formal and Informal }\end{array}$ & Susan J. Linz and Gary Krueger & April 1998 \\
\hline
\end{tabular}

Publications denoted by an asterisk are not available on the Kresge Library webpage (http://www.wdi.bus.umich.edu) 


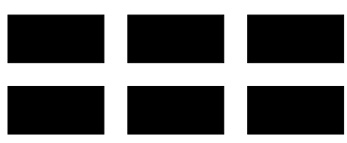

THE WILLIAM DAVIDSON INSTITUTE

AT THE UNIVERSITY OF MICHIGAN BUSINESSSCHOOL

\begin{tabular}{|c|c|c|}
\hline $\begin{array}{l}\text { Mechanisms."Vol. 40, No. 2, Summer 1998, } \\
\text { pp. 5-52. }\end{array}$ & & \\
\hline $\begin{array}{l}\text { No. 151: Labor Productivity in Transition: A } \\
\text { Regional Analysis of Russian Industry }\end{array}$ & Susan J. Linz & May 1998 \\
\hline $\begin{array}{l}\text { No. 150: Tax Avoidance and the Allocation of } \\
\text { Credit. Forthcoming in Financial Systems in } \\
\text { Transition: The Design of Financial Systems } \\
\text { in Central Europe eds. Anna Meyendorff and } \\
\text { Anjan Thakor. }\end{array}$ & Anna Meyendorff & June 1998 \\
\hline $\begin{array}{l}\text { No. 149: Commitment, Versatility and } \\
\text { Balance: Determinants of Work Time } \\
\text { Standards and Norms in a Multi-Country } \\
\text { Study of Software Engineers }\end{array}$ & Leslie Perlow and Ron Fortgang & April 1998 \\
\hline $\begin{array}{l}\text { No. 148: Changes in Poland's Transfer } \\
\text { Payments in the 1990s: the Fate of } \\
\text { Pensioners }\end{array}$ & Bozena Leven & June 1998 \\
\hline $\begin{array}{l}\text { No. 147: Environmental Protection and } \\
\text { Economic Development: The Case of the } \\
\text { Huaihe River Basin Cleanup Plan }\end{array}$ & $\begin{array}{l}\text { Robert Letovsky, Reze Ramazani, and } \\
\text { Debra Murphy }\end{array}$ & June 1998 \\
\hline $\begin{array}{l}\text { No. 146: Chief Executive Compensation } \\
\text { During Early Transition: Further Evidence } \\
\text { from Bulgaria }\end{array}$ & $\begin{array}{l}\text { Derek C. Jones, Takao Kato, and Jeffrey } \\
\text { Miller }\end{array}$ & June 1998 \\
\hline $\begin{array}{l}\text { No. } 145 \text { Published in: Economics of } \\
\text { Transition, “Women's Unemployment During } \\
\text { the Transition: Evidence from Czech and } \\
\text { Slovak Micro Data," Vol. 7, No. 1, May 1999, } \\
\text { pp. 47-78. }\end{array}$ & $\begin{array}{l}\text { John Ham, Jan Svejnar, and Katherine } \\
\text { Terrell }\end{array}$ & May 1998 \\
\hline No. 144: Investment and Wages in Slovenia & Janez Prasnikar & May 1998 \\
\hline $\begin{array}{l}\text { No. } 143 \text { Published in: Review of Financial } \\
\text { Studies, “Optimal Bankruptcy Laws Across } \\
\text { Different Economic Systems," 12(2), Summer } \\
\text { 1999, pgs. 347-77. }\end{array}$ & Elazar Berkovitch and Ronen Israel & March 1998 \\
\hline $\begin{array}{l}\text { No. 142: Industrial Policy and Poverty in } \\
\text { Transition Economies: Two Steps Forward or } \\
\text { One Step Back? }\end{array}$ & Susan J. Linz & March 1998 \\
\hline $\begin{array}{l}\text { No. 141: Collective Ownership and } \\
\text { Privatization of China's Village Enterprises }\end{array}$ & Suwen Pan and Albert Park & April 1998 \\
\hline $\begin{array}{l}\text { No. 140: A Comparative Look at Labor } \\
\text { Mobility in the Czech Republic: Where have } \\
\text { all the Workers Gone? }\end{array}$ & Vit Sorm and Katherine Terrell & April 1999 \\
\hline $\begin{array}{l}\text { No. 139: The Failure of the Government-Led } \\
\text { Program of Corporate Reorganization in } \\
\text { Romania }\end{array}$ & Simeon Djankov and Kosali Ilayperuma & September 1997 \\
\hline $\begin{array}{l}\text { No. 138: Ownership and Employment in } \\
\text { Russian Industry: 1992-1995 }\end{array}$ & Susan J. Linz & March 1998 \\
\hline $\begin{array}{l}\text { No. } 137 \text { Published in: Journal of Political } \\
\text { Economy, "Reform Without Losers: An } \\
\text { Interpretation of China's Dual-Track } \\
\text { Approach to Transition," Feb. 2000; Vol. 108, } \\
\text { Iss.1; pg. } 120\end{array}$ & $\begin{array}{l}\text { Lawrence J. Lau, Yingyi Qian, and Gerard } \\
\text { Roland }\end{array}$ & November 1997 \\
\hline $\begin{array}{l}\text { No. } 136 \text { Published in: European Economic } \\
\text { Review, "The Political Economy of Mass }\end{array}$ & Klaus M. Schmidt & March 1998 \\
\hline
\end{tabular}

Publications denoted by an asterisk are not available on the Kresge Library webpage (http://www.wdi.bus.umich.edu) 


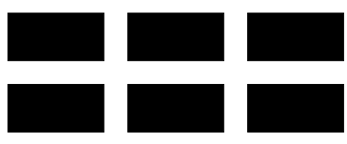

THE WILLIAM DAVIDSON INSTITUTE

AT THE UNIVERSITY OF MICHIGAN BUSINESSSCHOOL

\begin{tabular}{|c|c|c|}
\hline $\begin{array}{l}\text { Privatization and the Risk of Expropriation," } \\
44(2), \text { February 2000, pgs. 393-421 }\end{array}$ & & \\
\hline $\begin{array}{l}\text { No. 135: Radical Organizational Change: The } \\
\text { Role of Starting Conditions, Competition, and } \\
\text { Leaders }\end{array}$ & Karen L. Newman & January 1998 \\
\hline $\begin{array}{l}\text { No. 134: To Restructure or Not to } \\
\text { Restructure: Informal Activities and } \\
\text { Enterprise Behavior in Transition } \\
\text { No. 133: Management 101: Behavior of Firms } \\
\text { in Transition Economies }\end{array}$ & $\begin{array}{l}\text { Clifford Gaddy and Barry W. Ickes } \\
\text { Josef C. Brada }\end{array}$ & March 1998 \\
\hline $\begin{array}{l}\text { No. } 132 \text { Published in: Quarterly Journal of } \\
\text { Economics, "Interfirm Relationships and } \\
\text { Informal Credit in Vietnam," 114(4), Nov. } \\
\text { 1999, pgs. 1285-1320 }\end{array}$ & John McMillan and Christopher Woodruff & February 1998 \\
\hline $\begin{array}{l}\text { No. } 131 \text { Published in: Comparative Economic } \\
\text { Studies, “Will Restructuring Hungarian } \\
\text { Companies Innovate? An Investigation Based } \\
\text { on Joseph Berliner's Analysis of Innovation in } \\
\text { Soviet Industry." Vol. 40, No. 2, Summer } \\
\text { 1998, pp. 53-74. }\end{array}$ & John B. Bonin and Istvan Abel & March 1998 \\
\hline $\begin{array}{l}\text { No. 130: Published in The American } \\
\text { Economic Review, "Changing Incentives of } \\
\text { the Chinese Bureaucracy." May, 1998. }\end{array}$ & David D. Li & January 1998 \\
\hline $\begin{array}{l}\text { No. 129: Restructuring Investment in } \\
\text { Transition: A Model of the Enterprise } \\
\text { Decision }\end{array}$ & Richard E. Ericson & January 1998 \\
\hline $\begin{array}{l}\text { No. } 128 \text { Published in: Comparative Economic } \\
\text { Studies, “Job Rights in Russian Firms: } \\
\text { Endangered or Extinct Institutions?” Vol. 40, } \\
\text { No. 4, Winter 1998, pp. 1-32. }\end{array}$ & Susan J. Linz & January 1998 \\
\hline $\begin{array}{l}\text { No. 127: Accounting for Growth in Post- } \\
\text { Soviet Russia }\end{array}$ & Daniel Berkowitz and David N. DeJong & January 1998 \\
\hline $\begin{array}{l}\text { No. } 126 \text { Published in: Economics of } \\
\text { Transition, "From Federalism, Chinese Style, } \\
\text { to Privatization Chinese Style," } 7(1), 1999, \\
\text { pgs. } 103-31\end{array}$ & $\begin{array}{l}\text { Yuanzheng Cao, Yingyi Qian, and Barry R. } \\
\text { Weingast }\end{array}$ & December 1997 \\
\hline $\begin{array}{l}\text { No. 125: Market Discipline in Conglomerate } \\
\text { Banks: Is an Internal Allocation of Cost of } \\
\text { Capital Necessary as Incentive Device? } \\
\text { Forthcoming in Financial Systems in } \\
\text { Transition: The Design of Financial Systems } \\
\text { in Central Europe eds. Anna Meyendorff and } \\
\text { Anjan Thakor. }\end{array}$ & Arnoud W. A. Boot and Anjolein Schmeits & November 1997 \\
\hline $\begin{array}{l}\text { No. 124: Financial Discipline in the } \\
\text { Enterprise Sector in Transition Countries: } \\
\text { How Does China Compare? }\end{array}$ & Shumei Gao and Mark E. Schaffer & February 1998 \\
\hline $\begin{array}{l}\text { No. 123: Considerations of an Emerging } \\
\text { Marketplace: Managers' Perceptions in the } \\
\text { Southern African Economic Community }\end{array}$ & Brent Chrite and David Hudson & February 1998 \\
\hline $\begin{array}{l}\text { No. 122: A Model of the Informal Economy in } \\
\text { Transition Economies }\end{array}$ & $\begin{array}{l}\text { Simon Commander and Andrei } \\
\text { Tolstopiatenko }\end{array}$ & November 1997 \\
\hline No. 121: Local Labour Market Dynamics in & Peter Huber and Andreas Worgotter & November 1997 \\
\hline
\end{tabular}

Publications denoted by an asterisk are not available on the Kresge Library webpage (http://www.wdi.bus.umich.edu) 


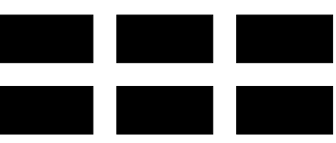

THE WILLIAM DAVIDSON INSTITUTE

AT THE UNIVERSITY OF MICHIGAN BUSINESSSCHOOL

\begin{tabular}{|c|c|c|}
\hline the Czech and Slovak Republics & & \\
\hline $\begin{array}{l}\text { No. 121: Local Labour Market Dynamics in } \\
\text { the Czech and Slovak Republics }\end{array}$ & Peter Huber and Andreas Worgotter & November 1997 \\
\hline $\begin{array}{l}\text { No. 119: Institutional Upheaval and Company } \\
\text { Transformation in Emerging Market } \\
\text { Economies }\end{array}$ & Karen L. Newman & March 1998 \\
\hline $\begin{array}{l}\text { No. 118: Industrial Decline and Labor } \\
\text { Reallocation in Romania }\end{array}$ & John S. Earle & October 1997 \\
\hline $\begin{array}{l}\text { No. 117: Notes for an Essay on the Soft } \\
\text { Budget Constraint }\end{array}$ & Lorand Ambrus-Lakatos & January 1997 \\
\hline $\begin{array}{l}\text { No. 116: Labor Demand During Transition in } \\
\text { Hungary }\end{array}$ & Gabor Korosi & October 1997 \\
\hline $\begin{array}{l}\text { No. 115: Enterprise Performance and } \\
\text { Managers' Profiles }\end{array}$ & Simeon Djankov and Stijn Claessens & December 1997 \\
\hline $\begin{array}{l}\text { No. } 114 \text { b Employment and Wages in } \\
\text { Enterprises under Communism and in } \\
\text { Transition: Evidence From Central Europe } \\
\text { and Russia }\end{array}$ & Swati Basu, Saul Estrin, and Jan Svejnar & April 2000 \\
\hline $\begin{array}{l}\text { No. 114: Employment and Wage Behavior of } \\
\text { Enterprises in Transitional Economies }\end{array}$ & Swati Basu, Saul Estrin, and Jan Svejnar & October 1997 \\
\hline $\begin{array}{l}\text { No. 113: Preliminary Evidence on Active } \\
\text { Labor Programs' Impact in Hungary and } \\
\text { Poland }\end{array}$ & Christopher J. O’Leary & October 1997 \\
\hline $\begin{array}{l}\text { No. 111: Unemployment Benefits and } \\
\text { Incentives in Hungary: New Evidence }\end{array}$ & Joachim Wolff & October 1997 \\
\hline $\begin{array}{l}\text { No. 110: Published in: Empirical Economics, } \\
\text { "Long-Term Unemployment, Unemployment } \\
\text { Benefits and Social Assistance: The Polish } \\
\text { Experience" Empirical-Economics; 23(1-2), } \\
\text { 1998, pages 55-85. }\end{array}$ & Marek Gora and Christoph M. Schmidt & April 1997 \\
\hline $\begin{array}{l}\text { No. } 109 \text { Published in: Industrial and Labor } \\
\text { Relations Review, “Markets for Communist } \\
\text { Human Capital: Returns to Education and } \\
\text { Experience in Post-Communist Czech } \\
\text { Republic and Slovakia.” Vol. 51, No. 3, April } \\
\text { 1998, pp. 401-423. }\end{array}$ & Robert S. Chase & October 1997 \\
\hline $\begin{array}{l}\text { No. 107: The Worker-Firm Matching in the } \\
\text { Transition: (Why) Are the Czechs More } \\
\text { Successful Than Others? }\end{array}$ & $\begin{array}{l}\text { Daniel Münich, Jan Svejnar, and } \\
\text { Katherine Terrell }\end{array}$ & October 1997 \\
\hline $\begin{array}{l}\text { No. } 106 \text { Published in: Journal of } \\
\text { Comparative Economics, “Job Creation, Job } \\
\text { Destruction and Growth of Newly Established, } \\
\text { Privatized and State-Owned Enterprises in } \\
\text { Transition Economies: Survey Evidence from } \\
\text { Bulgaria, Hungary, and Romania," Vol. 26, } \\
\text { No.3, September 1998, pp. 429-445. }\end{array}$ & Valentijn Bilsen and Jozef Konings & September 1998 \\
\hline $\begin{array}{l}\text { No. 105: Getting Behind the East-West } \\
\text { [German] Wage Differential: Theory and } \\
\text { Evidence }\end{array}$ & Michael Burda and Christoph Schmidt & May 1997 \\
\hline $\begin{array}{l}\text { No. 104: The Birth of the "Wage Curve" in } \\
\text { Hungary, 1989-95 }\end{array}$ & Gabor Kertesi and Janos Kollo & October 1997 \\
\hline No. 103: Published in: Journal of & Hartmut Lehmann, Jonathan Wadsworth, & October 1997 \\
\hline
\end{tabular}

Publications denoted by an asterisk are not available on the Kresge Library webpage (http://www.wdi.bus.umich.edu) 


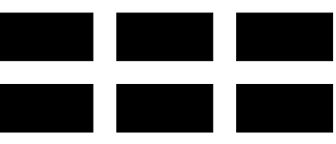

THE WILLIAM DAVIDSON INSTITUTE

AT THE UNIVERSITY OF MICHIGAN BUSINESSSCHOOL

\begin{tabular}{|c|c|c|}
\hline $\begin{array}{l}\text { Comparative Economics, "Grime and } \\
\text { Punishment: Job Insecurity and Wage Arrears } \\
\text { in the Russian Federation" 27, 595-617 } \\
\text { (1999). }\end{array}$ & and Alessandro Acquisti & \\
\hline No. 102: Social Networks in Transition & $\begin{array}{l}\text { Lorena Barberia, Simon Johnson, and } \\
\text { Daniel Kaufmann }\end{array}$ & October 1997 \\
\hline $\begin{array}{l}\text { No. 101: Depreciation and Russian Corporate } \\
\text { Finance: A Pragmatic Approach to Surviving } \\
\text { the Transition }\end{array}$ & Susan J. Linz & November 1997 \\
\hline No. 100: Romanian Financial System Reform & Anna Meyendorff and Anjan V. Thakor & November 1997 \\
\hline $\begin{array}{l}\text { No. 99: Proceedings of the Conference on } \\
\text { Strategic Alliances in Transitional Economies, } \\
\text { held May 20, } 1997 \text { at the Davidson Institute }\end{array}$ & Edited by Cynthia Koch & May 1997 \\
\hline $\begin{array}{l}\text { No. 98: Institutions, Strain and the } \\
\text { Underground Economy }\end{array}$ & Daniel Daianu and Lucian Albu & November 1997 \\
\hline $\begin{array}{l}\text { No. 97: Structure and Strain in Explaining } \\
\text { Inter-Enterprise Arrears } \\
\text { No. 96: Resource Misallocation and Strain: } \\
\text { Explaining Shocks in Post-Command } \\
\text { Economies }\end{array}$ & $\begin{array}{l}\text { Daniel Daianu } \\
\text { Daniel Daianu }\end{array}$ & $\begin{array}{l}\text { November } 1997 \\
\text { November } 1997\end{array}$ \\
\hline $\begin{array}{l}\text { No. 95: Published in: Finance-a-Uver, } \\
\text { "Czech Money Market: Emerging Links } \\
\text { Among Interest Rates.” 48(2) } 1998 \text { pp. 99- } \\
\text { 109. }\end{array}$ & Jan Hanousek and Evzen Kocenda & November 1997 \\
\hline $\begin{array}{l}\text { No. 94: Pre-Reform Industry and the } \\
\text { State Monopsony in China }\end{array}$ & Xiao-Yuan Dong and Louis Putterman & October 1997 \\
\hline $\begin{array}{l}\text { No. 93: China's State-Owned Enterprises } \\
\text { In the First Reform Decade: } \\
\text { An Analysis of a Declining Monopsony }\end{array}$ & Xiao-Yuan Dong and Louis Putterman & October 1997 \\
\hline $\begin{array}{l}\text { No. 92: Expatriate Management in the Czech } \\
\text { Republic }\end{array}$ & Richard B. Peterson & September 1997 \\
\hline $\begin{array}{l}\text { No. 91: China and the Idea of Economic } \\
\text { Reform }\end{array}$ & Thomas G. Rawski & April 1997 \\
\hline $\begin{array}{l}\text { No. } 90 \text { Published in: China Economic } \\
\text { Review, "China's State Enterprise Reform: An } \\
\text { Overseas Perspective." Vol. 8, Spring 1997, } \\
\text { pp. 89-98. }\end{array}$ & Thomas G. Rawski & July 1997 \\
\hline $\begin{array}{l}\text { No. 89: The Economic Determinants of } \\
\text { Internal Migration Flows in Russia During } \\
\text { Transition }\end{array}$ & Annette N. Brown & July 1997 \\
\hline $\begin{array}{l}\text { No. 88: Gender Wage Gaps in China's Labor } \\
\text { Market: Size, Structure, Trends }\end{array}$ & $\begin{array}{l}\text { Margaret Maurer-Fazio, Thomas G. } \\
\text { Rawski, and Wei Zhang }\end{array}$ & July 1997 \\
\hline $\begin{array}{l}\text { No. 87: Privatisation in Central and Eastern } \\
\text { Europe }\end{array}$ & Saul Estrin & June 1997 \\
\hline $\begin{array}{l}\text { No. 86: Published in : Economics of } \\
\text { Transition, "The Effect of Privatization on } \\
\text { Wealth Distribution in Russia." v. 7, no. 2, } \\
\text { 1999, pp. 449-65 }\end{array}$ & Michael Alexeev & February 1998 \\
\hline $\begin{array}{l}\text { No. 85: Was Privatization in Eastern Germany } \\
\text { a Special Case? Some Lessons from the } \\
\text { Treuhand }\end{array}$ & Uwe Siegmund & September 1997 \\
\hline No. 84: Start-ups and Transition & Daniel M. Berkowitz and David J. Cooper & September 1997 \\
\hline
\end{tabular}

Publications denoted by an asterisk are not available on the Kresge Library webpage (http://www.wdi.bus.umich.edu) 


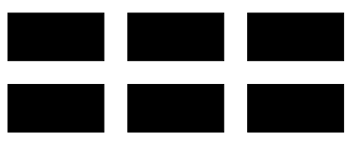

THE WILLIAM DAVIDSON INSTITUTE

AT THE UNIVERSITY OF MICHIGAN BUSINESSSCHOOL

\begin{tabular}{|c|c|c|}
\hline $\begin{array}{l}\text { No. 83: Which Enterprises (Believe They) } \\
\text { Have Soft Budgets after Mass Privatization? } \\
\text { Evidence from Mongolia }\end{array}$ & $\begin{array}{l}\text { James Anderson, Georges Korsun, and } \\
\text { Peter Murrell }\end{array}$ & October 1997 \\
\hline $\begin{array}{l}\text { No. 82: Published in: European Economic } \\
\text { Review, "Unemployment Dynamics and the } \\
\text { Restructuring of the Slovak Unemployment } \\
\text { Benefit System." April, 1997. }\end{array}$ & Martina Lubyova and Jan C. van Ours & June 1997 \\
\hline $\begin{array}{l}\text { No. 81: Determinants of Unemployment } \\
\text { Duration in Russia }\end{array}$ & Mark C. Foley & August 1997 \\
\hline $\begin{array}{l}\text { No. 80: The Many Faces of Information } \\
\text { Disclosure }\end{array}$ & Arnoud W.A. Boot and Anjan V. Thakor & October 1997 \\
\hline $\begin{array}{l}\text { No. 79: Published in: Journal of Finance, } \\
\text { "Foreign Speculators and Emerging Equity } \\
\text { Markets."v.22, iss. 2, 2000, pp. } 565-613\end{array}$ & Geert Bekaert and Campbell R. Harvey & August 1997 \\
\hline $\begin{array}{l}\text { No. 78: The Relationship Between Economic } \\
\text { Factors and Equity Markets in Central Europe }\end{array}$ & Jan Hanousek and Randall K. Filer & June 1997 \\
\hline $\begin{array}{l}\text { No. } 77 \text { Published in: Economics of } \\
\text { Transition, "A Gini Decomposition Analysis } \\
\text { of Inequality in the Czech and Slovak } \\
\text { Republics During the Transition," Vol. 6, } \\
\text { No.1, May 1998, pp. 23-46. }\end{array}$ & Thesia I. Garner and Katherine Terrell & May 1998 \\
\hline $\begin{array}{l}\text { No. 76: Chinese Enterprise Reform as a } \\
\text { Market Process }\end{array}$ & Gary H. Jefferson and Thomas G. Rawski & June 1997 \\
\hline $\begin{array}{l}\text { No. } 75 b \text { : Test of Permanent Income } \\
\text { Hypothesis on Czech Voucher Privatization }\end{array}$ & Jan Hanousek and Zdenek Tima & October 1997 \\
\hline $\begin{array}{l}\text { No. 74: Determinants of Performance of } \\
\text { Manufacturing Firms in Seven European } \\
\text { Transition Economies }\end{array}$ & $\begin{array}{l}\text { Stijn Claessens, Simeon Djankov, and } \\
\text { Gerhard Pohl }\end{array}$ & February 1997 \\
\hline $\begin{array}{l}\text { No. } 73 \text { Published in: Economics of } \\
\text { Transition, "The Restructuring of Large } \\
\text { Firms in Slovak Republic." Vol. 6, No. 1, May } \\
\text { 1998, pp. 67-85 }\end{array}$ & Simeon Djankov and Gerhard Pohl & May 1998 \\
\hline $\begin{array}{l}\text { No. 72: Law, Relationships, and Private } \\
\text { Enforcement: Transactional Strategies of } \\
\text { Russian Enterprises }\end{array}$ & $\begin{array}{l}\text { Kathryn Hendley, Peter Murrell, and } \\
\text { Randi Ryterman }\end{array}$ & November 1998 \\
\hline $\begin{array}{l}\text { No. 71: Giving Credit Where Credit Is Due: } \\
\text { The Changing Role of Rural Financial } \\
\text { Institutions in China }\end{array}$ & Albert Park, Loren Brandt, and John Giles & March 1997 \\
\hline $\begin{array}{l}\text { No. 70: Privatization Versus Competition: } \\
\text { Changing Enterprise Behavior in Russia }\end{array}$ & John S. Earle and Saul Estrin & Spring 1997 \\
\hline $\begin{array}{l}\text { No. 69: Russian Managers under Storm: } \\
\text { Explicit Reality and Implicit Leadership } \\
\text { Theories (A Pilot Exploration) }\end{array}$ & Igor Gurkov & October 1998 \\
\hline $\begin{array}{l}\text { No. 68: The Political Economy of Central- } \\
\text { Local Relations in China: Inflation and } \\
\text { Investment Controls During the Reform Era }\end{array}$ & Yasheng Huang & Spring 1997 \\
\hline $\begin{array}{l}\text { No. 67: Between Two Coordination Failures: } \\
\text { Automotive Industrial Policy in China with a } \\
\text { Comparison to Korea }\end{array}$ & Yasheng Huang & Spring 1997 \\
\hline $\begin{array}{l}\text { No. } 66 \text { Published in: Post-Soviet Geography } \\
\text { and Economics, "Red Executives in Russia's } \\
\text { Transition Economy." Vol. 27, No. 10, }\end{array}$ & Susan J. Linz & January 1997 \\
\hline
\end{tabular}

Publications denoted by an asterisk are not available on the Kresge Library webpage (http://www.wdi.bus.umich.edu) 


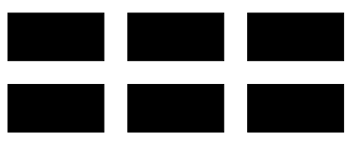

THE WILLIAM DAVIDSON INSTITUTE

AT THE UNIVERSITY OF MICHIGAN BUSINESSSCHOOL

\begin{tabular}{|c|c|c|}
\hline November 1996, pp. 633-651. & & \\
\hline $\begin{array}{l}\text { No. } 65 \text { Published in: Industrial and } \\
\text { Corporate Change, "On the Sequencing of } \\
\text { Privatization in Transition Economies." Vol. } \\
\text { 7, No. 1, 1998. }\end{array}$ & Gautam Ahuja and Sumit K. Majumdar & April 1997 \\
\hline $\begin{array}{l}\text { No. 64: Published in: Journal of Law and } \\
\text { Economics, "Foreign Ownership and } \\
\text { Profitability: Property Rights, Control and the } \\
\text { Performance of Firms in Indian Industry" } \\
\text { 42(1), April 1999, pp. 209-38. }\end{array}$ & $\begin{array}{l}\text { Pradeep K. Chhibber and Sumit K. } \\
\text { Majumdar }\end{array}$ & April 1997 \\
\hline $\begin{array}{l}\text { No. 63: How Taxing Is Corruption on } \\
\text { International Investors? }\end{array}$ & Shang-Jin Wei & February 1997 \\
\hline $\begin{array}{l}\text { No. 62: What Can We Learn from the } \\
\text { Experience of Transitional Economies with } \\
\text { Labour Market Policies? } \\
\text { No. 61: Published in: Accounting } \\
\text { Organizations and Society, "Economic } \\
\text { Transition, Strategy and the Evolution of } \\
\text { Management Accounting Practices: The Case } \\
\text { of India" 24(5,6), Jul/Aug 1999, pp. 379-412. }\end{array}$ & $\begin{array}{l}\text { Shannon W. Anderson and William N. } \\
\text { Lanen }\end{array}$ & $\begin{array}{l}1997 \\
\text { April } 1997\end{array}$ \\
\hline $\begin{array}{l}\text { No. 60a: Enterprise Investment During the } \\
\text { Transition: Evidence from Czech Panel Data }\end{array}$ & Lubomír Lizal and Jan Svejnar & December 1997 \\
\hline $\begin{array}{l}\text { No. 59: Published in: Journal of Law, } \\
\text { Economics, and Organization, "Institutional } \\
\text { Environment, Community Government, and } \\
\text { Corporate Governance: Understanding } \\
\text { China's Township-Village Enterprises." } \\
\text { 14(1), April 1998, pages 1-23 }\end{array}$ & Jiahua Che and Yingyi Qian & April 1997 \\
\hline $\begin{array}{l}\text { No. 58: From the Grabbing Hand to the } \\
\text { Helping Hand }\end{array}$ & Jiahua Che & June 2000 \\
\hline $\begin{array}{l}\text { No. 57: Published in: Brookings Papers on } \\
\text { Economic Activity, "The Unofficial Economy } \\
\text { in Transition." 1: 1998. }\end{array}$ & $\begin{array}{l}\text { Simon Johnson, Daniel Kaufmann, and } \\
\text { Andrei Schleifer }\end{array}$ & June 1997 \\
\hline $\begin{array}{l}\text { No. 56: Taxes and Government Incentives: } \\
\text { Eastern Europe vs. China }\end{array}$ & Roger H. Gordon and David D. Li & April 1997 \\
\hline No. 55: Corruption and Reform & Susanto Basu and David Li & June 1996 \\
\hline $\begin{array}{l}\text { No. 54: Decentralization and the } \\
\text { Macroeconomic Consequences of } \\
\text { Commitment to State-Owned Firms }\end{array}$ & Loren Brandt and Xiaodong Zhu & June 1997 \\
\hline $\begin{array}{l}\text { No. 53: Published in: The International } \\
\text { Journal of Industrial Organization, } \\
\text { "Competitive Shocks and Industrial Structure: } \\
\text { The Case of Polish Manufacturing." August, } \\
\text { 1999. . }\end{array}$ & Pankaj Ghemawat and Robert E. Kennedy & May 1997 \\
\hline $\begin{array}{l}\text { No. 52: Published in: The Quarterly Journal } \\
\text { of Economics, "Insecure Property Rights and } \\
\text { Government Ownership of Firms." May, } \\
\text { 1998. }\end{array}$ & Jiahua Che and Yingyi Qian & May 1997 \\
\hline $\begin{array}{l}\text { No. 51: Incentives, Scale Economies, and } \\
\text { Organizational Form }\end{array}$ & $\begin{array}{l}\text { Eric Maskin, Yingyi Qian, and Chenggang } \\
X u\end{array}$ & May 1997 \\
\hline $\begin{array}{l}\text { No. 50: Published in: Post-Soviet-Affairs, } \\
\text { "End of the Tunnel? The Effects of Financial }\end{array}$ & $\begin{array}{l}\text { Barry W. Ickes, Peter Murrell, and Randi } \\
\text { Ryterman }\end{array}$ & March 1997 \\
\hline
\end{tabular}

Publications denoted by an asterisk are not available on the Kresge Library webpage (http://www.wdi.bus.umich.edu) 


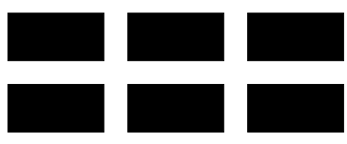

THE WILLIAM DAVIDSON INSTITUTE

AT THE UNIVERSITY OF MICHIGAN BUSINESSSCHOOL

\begin{tabular}{|c|c|c|}
\hline $\begin{array}{l}\text { Stabilization in Russia” April-June 1997, } \\
\text { pages 105-33 }\end{array}$ & & \\
\hline $\begin{array}{l}\text { No. 49: The Evolution of Bank Credit Quality } \\
\text { in Transition: Theory and Evidence from } \\
\text { Romania }\end{array}$ & Enrico C. Perotti and Octavian Carare & October 1996 \\
\hline $\begin{array}{l}\text { No. 48: Where Do the Leaders Trade? } \\
\text { Information Revelation and Interactions } \\
\text { Between the Segments of Czech Capital } \\
\text { Markets }\end{array}$ & Jan Hanousek and Libor Nemecek & May 1997 \\
\hline $\begin{array}{l}\text { No. 47: Firms' Heterogeneity in Transition: } \\
\text { Evidence from a Polish Panel Data Set }\end{array}$ & Irena Grosfeld and Jean-François Nivet & May 1997 \\
\hline $\begin{array}{l}\text { No. 46: Strategic Creditor Passivity, } \\
\text { Regulation, and Bank Bailouts }\end{array}$ & Janet Mitchell & May 1997 \\
\hline $\begin{array}{l}\text { No. } 45 \text { a: Decentralization in Transition } \\
\text { Economies: A Tragedy of the Commons? }\end{array}$ & Daniel M. Berkowitz and Wei Li & September 1997 \\
\hline $\begin{array}{l}\text { No. 44a: The Information Content of Stock } \\
\text { Markets: Why do Emerging Markets have } \\
\text { Synchronous Stock Price Movements? } \\
\text { (forthcoming in the Journal of Financial } \\
\text { Economics). } \\
\text { No. 43: Agency in Project Screening and } \\
\text { Termination Decisions: Why Is Good Money } \\
\text { Thrown After Bad? }\end{array}$ & $\begin{array}{l}\text { Randall Morck, Bernard Yeung, and } \\
\text { Wayne Yu } \\
\text { Chong-en Bai and Yijiang Wang }\end{array}$ & February 1999 \\
\hline $\begin{array}{l}\text { No. 42: Published in: Economics of } \\
\text { Transition, "Channels of Redistribution: } \\
\text { Inequality and Poverty in the Russian } \\
\text { Transition." Vol. } 7 \text { (2) } 1999 .\end{array}$ & $\begin{array}{l}\text { Simon Commander, Andrei Tolstopiatenko, } \\
\text { and Ruslan Yemtsov }\end{array}$ & May 1997 \\
\hline $\begin{array}{l}\text { No. 41: Published in: Economics of } \\
\text { Transition, "Labour Market Characteristics } \\
\text { and Profitability: Econometric Analysis of } \\
\text { Hungarian Exporting Firms, 1986-1995” } \\
\text { 6(1), May 1998, pages 145-62 }\end{array}$ & László Halpern and Gabor Korosi & May 1997 \\
\hline $\begin{array}{l}\text { No. 40: Published in: the Harvard Law } \\
\text { Review, "The Tragedy of the Anticommons: } \\
\text { Property in the Transition from Marx to } \\
\text { Markets." January 1998. }\end{array}$ & Michael Heller & February 1997 \\
\hline $\begin{array}{l}\text { No. 39: Privatization and Managerial } \\
\text { Efficiency }\end{array}$ & Olivier Debande and Guido Friebel & May 1997 \\
\hline $\begin{array}{l}\text { No. } 38 \text { Published in: The Quarterly Journal } \\
\text { of Economics, "Disorganization." Vol. 112, } \\
\text { No. 4, November 1997, pp. 1091-1126. }\end{array}$ & Olivier Blanchard and Michael Kremer & January 1997 \\
\hline $\begin{array}{l}\text { No. 37: Published in: Economics of } \\
\text { Transition, "Transition and the Output Fall." } \\
\text { 7(1), 1999, pages 1-28. }\end{array}$ & Gérard Roland and Thierry Verdier & March 1997 \\
\hline $\begin{array}{l}\text { No. 36: Restructuring an Industry During } \\
\text { Transition: A Two-Period Model }\end{array}$ & Richard Ericson & September 1996 \\
\hline $\begin{array}{l}\text { No. 34: The East-West Joint Venture: BC } \\
\text { Torsion Case Study }\end{array}$ & Sonia Ferencikova and Vern Terpstra & December 1998 \\
\hline $\begin{array}{l}\text { No. } 33 \text { Published in: Journal of Comparative } \\
\text { Economics, "Quantifying Price Liberalization } \\
\text { in Russia." Vol. 26, No. 4, December 1998, } \\
\text { pp. } 735-737 .\end{array}$ & $\begin{array}{l}\text { Daniel Berkowitz, David DeJong, and } \\
\text { Steven Husted }\end{array}$ & December 1998 \\
\hline
\end{tabular}

Publications denoted by an asterisk are not available on the Kresge Library webpage (http://www.wdi.bus.umich.edu) 


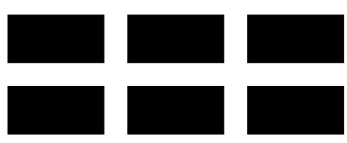

THE WILLIAM DAVIDSON INSTITUTE

AT THE UNIVERSITY OF MICHIGAN BUSINESSSCHOOL

\begin{tabular}{|c|c|c|}
\hline $\begin{array}{l}\text { No. 32: What Can North Korea Learn from } \\
\text { China's Market Reforms? }\end{array}$ & John McMillan & September 1996 \\
\hline $\begin{array}{l}\text { No. 31: Published in : China-Economic- } \\
\text { Review, “Towards a Model of China as a } \\
\text { Partially Reformed Developing Economy } \\
\text { Under a Semifederalist Government.", 9(1), } \\
\text { Spring 1998, pages 1-23. }\end{array}$ & Yijiang Wang and Chun Chang & March 1997 \\
\hline $\begin{array}{l}\text { No. 30: Convergence in Output in Transition } \\
\text { Economies: Central and Eastern Europe, } \\
\text { 1970-1995 }\end{array}$ & Saul Estrin and Giovanni Urga & February 1997 \\
\hline $\begin{array}{l}\text { No. 29: Published in: Economics of } \\
\text { Transition, "Altered Band and Exchange } \\
\text { Volatility." Volume 6, no. 1, 1998, 173-181. }\end{array}$ & Evzen Kocenda & March 1997 \\
\hline $\begin{array}{l}\text { No. 28: Published in: Quarterly Journal of } \\
\text { Economics, "Public Versus Private } \\
\text { Ownership of Firms: Evidence from Rural } \\
\text { China." Volume 113, no. 3, August 1998, 773- } \\
\text { 808. }\end{array}$ & Hehui Jin and Yingyi Qian & January 1997 \\
\hline $\begin{array}{l}\text { No. 27: East-West Joint Ventures in a } \\
\text { Transitional Economy: The Case of Slovakia }\end{array}$ & Sonia Ferencikova & March 1997 \\
\hline $\begin{array}{l}\text { No. 26: Published in Economic Analysis } \\
\text { "Behavior of a Slovenian Firm in Transition" } \\
\text { Vol. 1, no. 1, 1998, 57-73. }\end{array}$ & Janez Prasnikar & February 1997 \\
\hline $\begin{array}{l}\text { No. 25: Cultural Encounters and Claims to } \\
\text { Expertise in Postcommunist Capitalism }\end{array}$ & Michael D. Kennedy & February 1997 \\
\hline $\begin{array}{l}\text { No. 24: ZVU a.s.: Investment Funds on the } \\
\text { Board of Directors of an Engineering Giant }\end{array}$ & Tory Wolff & August 1995 \\
\hline $\begin{array}{l}\text { No. 23: The Role of Investment Funds in the } \\
\text { Czech Republic (joint publication with Czech } \\
\text { Management Center) }\end{array}$ & Dusan Triska & June 1996 \\
\hline $\begin{array}{l}\text { No. 22: Czech Investment Fund Industry: } \\
\text { Development and Behaviour (joint publication } \\
\text { with Czech Management Center) }\end{array}$ & Richard Podpiera & May 1996 \\
\hline $\begin{array}{l}\text { No. 21: Restructuring of Czech Firms: An } \\
\text { Example of Gama, a.s. (joint publication with } \\
\text { Czech Management Center) }\end{array}$ & Antonin Bulin & June 1996 \\
\hline $\begin{array}{l}\text { No. 20: YSE Funds: A Story of Czech } \\
\text { Investment Funds (joint publication with } \\
\text { Czech Management Center) }\end{array}$ & Michal Otradovec & November 1995 \\
\hline $\begin{array}{l}\text { No. 19: Prvni Investicni a.s., The First } \\
\text { Investment Corporation (joint publication } \\
\text { with Czech Management Center) }\end{array}$ & Jaroslav Jirasek & August 1995 \\
\hline $\begin{array}{l}\text { No. 18: PPF a.s., The First Private Investment } \\
\text { Fund (joint publication with Czech } \\
\text { Management Center) }\end{array}$ & Michal Otradovec & November 1995 \\
\hline $\begin{array}{l}\text { No. } 17 \text { Published in: Post-Soviet Geography } \\
\text { and Economics, "Russia's Managers in } \\
\text { Transition: Pilferers or Paladins?" Vol. 37, } \\
\text { o.7 (September 1996), pp. 397-426. }\end{array}$ & Susan J. Linz and Gary Krueger & November 1996 \\
\hline $\begin{array}{l}\text { No. 16: Banks in Transition-Investment } \\
\text { Opportunities in Central Europe and Russia } \\
\text { Edited Transcript from } 31 \text { May } 1996\end{array}$ & $\begin{array}{l}\text { With commentary and edited by Anna } \\
\text { Meyendorff }\end{array}$ & January 1997 \\
\hline
\end{tabular}

Publications denoted by an asterisk are not available on the Kresge Library webpage (http://www.wdi.bus.umich.edu) 


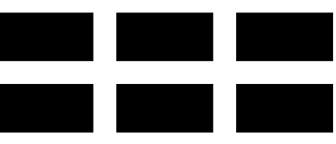

THE WILLIAM DAVIDSON INSTITUTE

AT THE UNIVERSITY OF MICHIGAN BUSINESSSCHOOL

\begin{tabular}{|c|c|c|}
\hline Conference in New York City & & \\
\hline $\begin{array}{l}\text { No. 15: Marketing in Transitional Economies: } \\
\text { Edited Transcript \& Papers from } 1 \text { April } 1996 \\
\text { Conference in Ann Arbor, Michigan }\end{array}$ & Compiled by The Davidson Institute & December 1996 \\
\hline $\begin{array}{l}\text { No. 14: Pensions in the Former Soviet Bloc: } \\
\text { Problems and Solutions. Published by } \\
\text { Council on Foreign Relations. "The Coming } \\
\text { Global Pension Crisis" New York, } 1997\end{array}$ & Jan Svejnar & November 1996 \\
\hline $\begin{array}{l}\text { No. 13: Enterprise Restructuring and } \\
\text { Performance in the Transition. Forthcoming } \\
\text { in Financial Systems in Transition: The } \\
\text { Design of Financial Systems in Central } \\
\text { Europe eds. Anna Meyendorff and Anjan } \\
\text { Thakor. }\end{array}$ & $\begin{array}{l}\text { Lubomir Lizal, Miroslav Singer, and Jan } \\
\text { Svejnar }\end{array}$ & December 1996 \\
\hline $\begin{array}{l}\text { No. } 12 \text { Published in: Journal of International } \\
\text { Marketing, "Executive Insights: Marketing } \\
\text { Issues and Challenges in Transitional } \\
\text { Economies." Vol. 5, No. 4, 1997, pp. 95-114. } \\
\text { Also published in: Marketing Issues in } \\
\text { Transitional Economies ed. Rajeev Batra. }\end{array}$ & Rajeev Batra & April 1997 \\
\hline $\begin{array}{l}\text { No. 11: Worker Trust and System } \\
\text { Vulnerability in the Transition from Socialism } \\
\text { to Capitalism }\end{array}$ & Andrew Schotter & August 1996 \\
\hline $\begin{array}{l}\text { No. } 10 \text { Published in: Comparative Economic } \\
\text { Studies, "Russian Firms in Transition: } \\
\text { Champions, Challengers, and Chaff." Vol. } \\
\text { 39, No.2, Summer 1997, pp. 1-36. }\end{array}$ & Susan J. Linz & July 1996 \\
\hline $\begin{array}{l}\text { No. 9: Corporate Debt Crisis and Bankruptcy } \\
\text { Law During the Transition: The Case of China }\end{array}$ & David D. Li and Shan Li & December 1995 \\
\hline $\begin{array}{l}\text { No. } 8 \text { Published in: Journal of Comparative } \\
\text { Economics, "A Theory of Ambiguous } \\
\text { Property Rights in Transition Economies: The } \\
\text { Case of the Chinese Non-State Sector." Vol. } \\
\text { 23, No. 1, August 1996, pp. 1-19. }\end{array}$ & David D. Li & June 1996 \\
\hline $\begin{array}{l}\text { No. 7: The Foreign Economic Contract Law of } \\
\text { China: Cases and Analysis }\end{array}$ & Dong-lai Li & June 1993 \\
\hline $\begin{array}{l}\text { No. 3: Bank Privatization in Hungary and the } \\
\text { Magyar Kulkereskedelmi Bank Transaction }\end{array}$ & Roger Kormendi and Karen Schnatterly & May 1996 \\
\hline $\begin{array}{l}\text { Replacing Nos. 1-2 \& 4-6: Journal of } \\
\text { Comparative Economics Symposium on } \\
\text { "Bank Privatization in Central Europe and } \\
\text { Russia." Vol. 25, No. 1, August 1997. }\end{array}$ & $\begin{array}{l}\text { No. } 1 \text { "Bank Privatization in Transitional } \\
\text { Economies" by Roger Kormendi and } \\
\text { Edward Snyder. No. } 2 \text { "Transactional } \\
\text { Structures of Bank Privatizations in } \\
\text { Central Europe and Russia” by Anna } \\
\text { Meyendorff and Edward A. Snyder. No. } 4 \\
\text { "Bank Privatization in Poland: The Case } \\
\text { of Bank Slaski" by Jeffery Abarbaness and } \\
\text { John Bonin. No. } 5 \text { "Bank Privatization in } \\
\text { Post-Communist Russia: The Case of } \\
\text { Zhilsotsbank" by Jeffery Abarbanell and } \\
\text { Anna Meyendorff and No. } 6 \text { "'The Czech } \\
\text { Republic's Commercial Bank: Komercni } \\
\text { Banka" by Edward A. Snyder and Roger }\end{array}$ & August 1997 \\
\hline
\end{tabular}

Publications denoted by an asterisk are not available on the Kresge Library webpage (http://www.wdi.bus.umich.edu) 


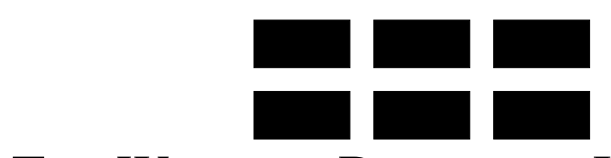

THE WILLIAM DAVIDSON INSTITUTE

AT THE UNIVERSITY OF MICHIGAN BUSINESS SCHOOL

C. Kormendi.

1

Publications denoted by an asterisk are not available on the Kresge Library webpage (http://www.wdi.bus.umich.edu) 